\title{
Dietary and pharmacological compounds altering intestinal calcium absorption in humans and animals
}

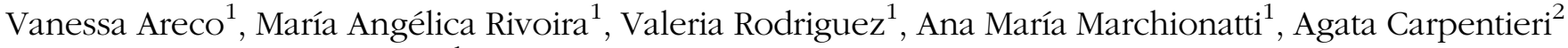 \\ and Nori Tolosa de Talamoni ${ }^{1 *}$ \\ ${ }^{1}$ Laboratorio 'Dr. Cañas', Cátedra de Bioquímica y Biología Molecular, Facultad de Ciencias Médicas, INICSA \\ (CONICET-Universidad Nacional de Córdoba), Córdoba, Argentina \\ ${ }^{2}$ Cátedra de Química Biológica, Facultad de Odontología, INICSA (CONICET-Universidad Nacional de Córdoba), \\ Córdoba, Argentina
}

\section{Abstract}

The intestine is the only gate for the entry of Ca to the body in humans and mammals. The entrance of Ca occurs via paracellular and intracellular pathways. All steps of the latter pathway are regulated by calcitriol and by other hormones. Dietary and pharmacological compounds also modulate the intestinal $\mathrm{Ca}$ absorption process. Among them, dietary $\mathrm{Ca}$ and $\mathrm{P}$ are known to alter the lipid and protein composition of the brush-border and basolateral membranes and, consequently, Ca transport. Ca intakes are below the requirements recommended by health professionals in most countries, triggering important health problems. Chronic low Ca intake has been related to illness conditions such as osteoporosis, hypertension, renal lithiasis and incidences of human cancer. Carbohydrates, mainly lactose, and prebiotics have been described as positive modulators of intestinal Ca absorption. Apparently, high meat proteins increase intestinal Ca absorption while the effect of dietary lipids remains unclear. Pharmacological compounds such as menadione, DL-butionine-S,R-sulfoximine and ursodeoxycholic acid also modify intestinal $\mathrm{Ca}$ absorption as a consequence of altering the redox state of the epithelial cells. The paracellular pathway of intestinal $\mathrm{Ca}$ absorption is poorly known and is under present study in some laboratories. Another field that needs to be explored more intensively is the influence of the gene $\times$ diet interaction on intestinal Ca absorption. Health professionals should be aware of this knowledge in order to develop nutritional or medical strategies to stimulate the efficiency of intestinal Ca absorption and to prevent diseases.

\section{Key words: Intestinal calcium absorption: Transcellular and paracellular pathways: Hormonal effects: Nutritional factors}

\section{Introduction}

$\mathrm{Ca}$ is the main mineral component of bone and, hence, is essential for achieving optimal peak bone mass in the first decades of life and for maintaining bone mass, later in life ${ }^{(1)}$. It also plays an important role in many physiological processes $^{(2-5)}$. The dysregulation of Ca homeostasis is not only associated with bone disorders, but also with hypertension, insulin resistance, obesity and the metabolic syndrome ${ }^{(6-9)}$. Epidemiological and experimental studies have shown an inverse relationship between dietary $\mathrm{Ca}$ and risk of breast, colon, prostate and ovarian cancer ${ }^{(10-13)}$. Therefore, an appropriate $\mathrm{Ca}$ homeostasis preserves bone integrity, metabolic balance and avoids epithelial cancers.

Ca metabolism is predominantly regulated by the intestine, kidney, bone and parathyroid glands. Because of their coordinated work, serum Ca concentration is maintained within a narrow range ${ }^{(14)}$. Intestinal $\mathrm{Ca}$ absorption is an essential process that occurs through an active transcellular pathway and a passive non-saturable route, named the paracellular pathway ${ }^{(15)}$. Both routes are regulated by hormones, nutrients and many other factors.

The transcellular pathway is a saturable process, which is prevalent in the proximal small intestine (duodenum and jejunum), vitamin D being the main modulator. This mechanism is energy dependent and implicates Ca movement from the mucosal to serosal side of the intestinal barrier occurring against a concentration gradient. In contrast, the paracellular mechanism occurs throughout the length of the intestine. It is a non-saturable and passive transport and is a linear function of $\mathrm{Ca}$ concentration in the lumen ${ }^{(16)}$.

$\mathrm{Ca}^{2+}$ ions are absorbed mainly in the small intestine, which is responsible for about $90 \%$ of overall Ca absorption. The longer residence time in the ileum as compared with the other

Abbreviations: $1,25(\mathrm{OH})_{2} \mathrm{D}_{3}, 1,25$-dihydroxycholecalciferol; Al, aluminium ions; AP, alkaline phosphatase; BMD, bone mineral density; BSO, dl-buthionine(S,R)-sulfoximine; CB, calbindin; CPP, caseinophosphopeptides; ER, oestrogen receptor; FCA, fractional Ca absorption; FGF-23, fibroblast growth factor-23; GC, glucocorticoid; GSH, glutathione; IGF-1, insulin-like growth factor-1; KO, knockout; MEL, melatonin; MEN, menadione; NaDOC, sodium deoxycholate; NCX1, intestinal $\mathrm{Na}^{+} / \mathrm{Ca}^{2+}$ exchanger; OVX, ovariectomised; PMCA, plasma membrane $\mathrm{Ca}^{2+}$ ATPase; PTH, parathyroid hormone; TRP, transient receptor potential; TRPV, transient receptor potential vanilloid; UDCA, ursodeoxycholic acid; VDD, vitamin D deficiency; VDR, vitamin D receptor.

* Corresponding author: Professor Dr Nori Tolosa de Talamoni, fax +543543435000, email ntolosa@biomed.fcm.unc.edu.ar, ntolosatalamoni@yahoo.com.ar 
segments of the small intestine favours $\mathrm{Ca}$ absorption in that segment ${ }^{(16)}$. In rat ileum the transit half-time is about 100-120 $\mathrm{min}$, whereas in the duodenum it is about 2-6 $\mathrm{min}^{(17)}$. The colon is responsible for less than $10 \%$ of the total $\mathrm{Ca}$ absorbed; minor amounts of $\mathrm{Ca}^{2+}$ ions are absorbed from the stomach and large intestine ${ }^{(16)}$. The major contributors to the amount of $\mathrm{Ca}$ absorbed are the residence time and the absorption rate in each intestinal segment. The order of $\mathrm{Ca}$ absorption rate is: duodenum $>$ jejunum $>$ ileum ${ }^{(16)}$. Ca absorption in the colon is probably very important in pathological conditions such as short bowel syndrome ${ }^{(18)}$.

Intestinal $\mathrm{Ca}$ absorption also depends on the physiological needs of $\mathrm{Ca}$. When the requirements increase and/or the intakes are low, there is an improvement in the efficiency of $\mathrm{Ca}$ absorption ${ }^{(19)}$. Ageing occurs with a decrease in intestinal Ca absorption ${ }^{(20)}$, while growth, pregnancy and lactation promote cation absorption ${ }^{(21-24)}$. There is little information about the mechanism of lactation-induced intestinal hyperabsorption. Increases have been found in the villous height, villous width and crypt depth with an expansion of the absorptive surface area in the duodenum of $21 \mathrm{~d}$ lactating rats. An enhancement in claudin 15 has been also demonstrated in the same animal model ${ }^{(25)}$. Recently, Teerapornpuntakit et al. ${ }^{(26)}$ have developed a custom-designed cDNA microarray (CalGene Array) to study the expression of genes related to duodenal nutrient transport, among them those related to bone and $\mathrm{Ca}$ metabolism. They have determined the transcriptome responses of duodenal epithelial cells in pregnant and lactating rats; data were subsequently validated by quantitative real-time PCR. They have found that pregnancy and late lactation alter the expression of several transcripts, among them those belonging to $\mathrm{Ca}$ transporters.

\section{Transcellular pathway}

\section{Epithelial calcium channels}

TRPV6 (previously named ECaC2 or CaT1) and TRPV5 (previously named ECaC1 or CaT2) are the two epithelial $\mathrm{Ca}$ channels involved in Ca entry to the enterocytes. These channels are homologous members of the transient receptor potential (TRP) superfamily, belonging to the vanilloid subfamily (TRPV), which is different from the canonical (TRPC) and melastatin (TRPM) subfamilies ${ }^{(27)}$. TRPV6 and TRPV5 are co-expressed in the human kidney and intestine, but the first one is highly expressed in the intestine and the latter is the major isoform in the kidney. TRPV6 seems to be a major contributor to apical, intestinal Ca absorption, as suggested by a significant reduction in $\mathrm{Ca}$ absorption and serum $\mathrm{Ca}$ shown in TRPV6 knockout $(\mathrm{KO})$ mice ${ }^{(28,29)}$. Both channels are also expressed in the pancreas, prostate, and mammary, sweat and salivary glands ${ }^{(27)}$. They present a similar structure to other members of the TRP family: six transmembrane domains, a short hydrophobic stretch between segments 5 and 6 involved in the Ca pore and large intracellular $\mathrm{N}$ and $\mathrm{C}$ terminal tails. The intracellular segments contain phosphorylation sites, postsynaptic density protein motifs and ankyrin repeat domains; all of them are involved in the regulation of channel activity and trafficking ${ }^{(30)}$. It has been demonstrated that the tetrameric structure of TRPV6 and TRPV5 can be combined with each other to form different heterotetrameric channel complexes ${ }^{(31)}$. Both channels have $75 \%$ homology, share several properties, but have different $\mathrm{N}$ and $\mathrm{C}$ terminal tails. They are regulated by calcitriol, oestrogen and dietary Ca. Both are inactivated by intracellular $\mathrm{Ca}$, but with a different kinetics. In addition, the affinity of TRPV5 for the inhibitor ruthenium red is 100-fold that of TRPV6 ${ }^{(32)}$.

TRPV6 transcripts have been found in duodenum, but not in ileum, human biopsies. The duodenal expression of TRPV6 in men was detected to be vitamin D dependent, whereas in elderly women the TRPV6 and vitamin D receptor (VDR) expressions were low and not vitamin D dependent. This finding could explain, at least in part, the lower intestinal $\mathrm{Ca}$ absorption in elderly postmenopausal women ${ }^{(33)}$. In rats, the basal mRNA expression of TRPV6 has been found to be the highest in the duodenum, followed by the colon ( $46 \%$ of duodenum), and negligible in the jejunum and ileum. The rank order of the basal levels of TRVP6 protein was duodenum $>$ colon $(72 \%$ of duodenum) $>$ ileum $(25 \% \text { of duodenum })^{(34)}$.

\section{Calbindins}

These proteins appear to be responsible for carrying $\mathrm{Ca}^{2+}$ from the apical side of the enterocyte to the basal region of the cell. Calbindin $(\mathrm{CB}) \mathrm{CB}_{9 \mathrm{k}}$ is present in the intestine of mammals and $\mathrm{CB}_{28 \mathrm{k}}$ in that from avian species ${ }^{(35)}$. $\mathrm{CB}_{9 \mathrm{k}}$ has four $\alpha$-helical regions forming an EF-hand pair consisting of a canonical and a non-canonical/pseudo EF-hand domain, which are joined by a linker region. These EF-hands organised in tandem domains are the physiological relevant structures and two $\mathrm{Ca}^{2+}$ ions bind with positive cooperativity ${ }^{(36)} \cdot \mathrm{CB}_{28 \mathrm{k}}$ has six EF-hand domains, four of which bind $\mathrm{Ca}^{2+}$ with medium/high affinity ${ }^{(37)}$. EF-hand 2 is non-functional and under physiological conditions EF6 most probably is as well. The four medium/high-affinity sites ${ }^{(38)}$ are considered $\mathrm{Ca}$ specific.

$\mathrm{CB}$ also buffer $\mathrm{Ca}^{2+}$ ions by keeping intracellular $\mathrm{Ca}^{2+}$ concentrations below $10^{-7} \mathrm{M}$, which contribute to the prevention of premature cell death by apoptosis. When there is a downregulation of $\mathrm{CB}$, an excess of $\mathrm{Ca}^{2+}$ is provoked that may trigger apoptosis in the epithelial cells ${ }^{(39)}$. Furthermore, it has been reported that $\mathrm{CB}_{28 \mathrm{k}}$ also inhibits apoptosis in osteoblastic cells $^{(40)}$ and in germ cells from Robertsonian mice ${ }^{(41,42)}$. In addition, it has been shown in kidney that $\mathrm{CB}_{28 \mathrm{k}}$ regulates the $\mathrm{Ca}^{2+}$ concentration in the vicinity of the TRPV5 pore by a direct association with the channel ${ }^{(43)}$. This might occur in the intestine and in other tissues with important movements in intracellular $\mathrm{Ca}^{2+}$ concentrations.

Genetic studies have provided information that confused the understanding of $\mathrm{CB}$ on $\mathrm{Ca}$ homeostasis. Mice with ablation of the $\mathrm{CB}_{28 \mathrm{k}}$ gene do not exhibit calcemic abnormalities ${ }^{(44)}$. In $\mathrm{CB}_{9 \mathrm{k}}$-null mutant mice as well as mice lacking the epithelial $\mathrm{Ca}$ channel TRPV6 it has been demonstrated that the regulation of active intestinal $\mathrm{Ca}$ absorption is independent of $\mathrm{CB}_{9 \mathrm{k}}$ and TRPV6. The authors think that in the $\mathrm{KO}$ mice there is compensation by another $\mathrm{Ca}^{2+}$ channel or protein and that other novel factors are involved in intestinal Ca absorption ${ }^{(45)}$. It has 
been found that an ablation of $\mathrm{CB}_{9 \mathrm{k}}$ alters the expression of paracellular tight junction genes. The compensatory expression of paracellular tight junction genes in the duodenum was associated with $\mathrm{CB}_{9 \mathrm{k}}$, but not with $\mathrm{CB}_{28 \mathrm{k}}{ }^{(46)}$. This interaction between the transcellular and paracellular pathways might partially explain the variety of gut responses to absorb Ca under different pathophysiological conditions.

\section{Calcium pump and $\mathrm{Na}^{+} / \mathrm{Ca}^{2+}$ exchanger}

Plasma membrane $\mathrm{Ca}^{2+}$-ATPase (PMAC) 1 is an ATP-dependent transporter that pumps Ca out of the cytosol. This protein was detected in erythrocyte membranes and found to have a high $\mathrm{Ca}^{2+}$ affinity ${ }^{(47)}$. It presents four isoforms (PMCA1-4), which are divided into several subtypes by alternative splicing. PMCA1 is considered as the housekeeping isoform because its mRNA is in all tissues. The correlation between the regulation of $\mathrm{Ca}$ homeostasis by TRPV6 and PMCA1 and duodenal and renal function is not well known. Nevertheless, some reports have described a role for TRPV6 and PMCA1 in the uterus, duodenum, kidney and brain ${ }^{(48-52)}$. PMCA has a relative molecular mass $\left(\mathrm{M}_{\mathrm{r}}\right)$ of $130 \mathrm{kDa}$ and a $K_{\mathrm{m}}$ for $\mathrm{Ca}^{2+}$ of $0.2 \mu \mathrm{m}$ in the presence of calmodulin ${ }^{(53)}$. In the intestine, PMCA is located in the caveolae, which can exist in open and closed forms that control $\mathrm{Ca}^{2+}$ efflux from the cell ${ }^{(54)}$. The predominant form in the intestine is the isoform PMCA $1 \mathrm{~b}$. We have found that its expression and activity are higher in enterocytes from the villus tip than in those from the villus crypt, supporting the idea that mature enterocytes have the greatest capacity for transcellular $\mathrm{Ca}^{2+}$ movement ${ }^{(55)}$

Another novel protein seems to be crucial in the transcellular $\mathrm{Ca}^{2+}$ pathway. This is the protein $4.1 \mathrm{R}$, which was also first identified in the erythrocyte membrane skeleton and is expressed in the epithelia of the intestine. So far, its physiological function remains unknown. Liu et al. ${ }^{(56)}$ have detected that 4.1R co-localises with $\mathrm{PMCA}_{1 \mathrm{~b}}$. These authors have shown that 4.1R KO mice exhibit deterioration in intestinal $\mathrm{Ca}$ absorption. In $4.1 \mathrm{R} \mathrm{KO}$ mice, the expression of $\mathrm{PMCA}_{1 \mathrm{~b}}$ in enterocytes was decreased. This finding that the deficiency in the adaptor protein $4.1 \mathrm{R}$ produces an impaired intestinal $\mathrm{Ca}$ absorption suggests that many yet to be defined molecules might also play important functions in epithelial $\mathrm{Ca}$ transport.

Apparently, the intestinal $\mathrm{Na}^{+} / \mathrm{Ca}^{2+}$ exchanger (NCX1) is responsible for about $20 \%$ of $\mathrm{Ca}$ exit. However, this protein has received little attention and many recent reviews ignore it as another molecule involved in the $\mathrm{Ca}^{2+}$ exit from the intestine. The activity of the intestinal $\mathrm{Na}^{+} / \mathrm{Ca}^{2+}$ exchanger depends on the gradient created by $\mathrm{Na}^{+} / \mathrm{K}^{+}$-ATPase ${ }^{(57)}$. There are several isoforms that result from three different genes ${ }^{(58)}$, but in the intestine NCX1 is present mainly in the enterocytes. It has been detected in rats ${ }^{(57)}$, mice ${ }^{(59)}$, chicks ${ }^{(55)}$, horses ${ }^{(60)}$ and dogs ${ }^{(61)}$, but not in rabbits ${ }^{(62)}$. NCX1 has a stoichiometry of $3 \mathrm{Na}^{+}: 1 \mathrm{Ca}^{2+}$ and can function in either a forward mode $\left(\mathrm{Ca}^{2+}\right.$ extrusion) or in a reversed mode $\left(\mathrm{Ca}^{2+}\right.$ entry), depending on the $\mathrm{Na}^{+}$and $\mathrm{Ca}$ gradients and the membrane potential ${ }^{(63)}$. We have found that the expression and activity of NCX1 are quite similar between mature and immature enterocytes from chick duodenum, but are slightly higher in the villus tip cells ${ }^{(55)}$. Recently, it has been found that the gene expression of NCX1, $\mathrm{PMCA}_{1 \mathrm{~b}}$ and $\mathrm{CB}_{9 \mathrm{k}}$ was down-regulated, whereas NCX1 expression was unchanged in the duodenum of a model of hypoxia in pregnant rats that shares clinical similarities with humans suffering from preeclampsia or other metabolic diseases. The authors have also found alterations in $\mathrm{Ca}^{2+}$ transporters from the placenta and kidney and showed that these changes caused Ca deficiencies associated with pre-eclampsia ${ }^{(64)}$. As they pointed out, it is quite possible that this study may contribute to a better understanding of the interrelationship between $\mathrm{Ca}$ imbalances and metabolic disturbances during pre-eclampsia pathogenesis.

\section{Paracellular pathway}

The intestinal epithelium is formed by a continuous layer of individual cells with very narrow spaces between them through which small molecules and ions diffuse ${ }^{(65)}$. The epithelium must regulate this paracellular pathway for the maintenance of selective permeability. The movement of molecules and ions through this pathway is regulated by tight junctions. They are intercellular structures where plasma membranes of adjacent enterocytes have very close contact. The tight junction proteins are synthesised in the adjacent cells and they include occludin (Ocln) and claudins (Cldns). The latter is a protein family with more than twenty members. Both Ocln and Cldns are integral proteins having the capability of interacting adhesively with complementary molecules on adjacent cells and of co-polymerising laterally ${ }^{(66)} \cdot \mathrm{Ca}^{2+}$ movement through the tight junctions is a passive process that depends on the concentration and the electric gradient across the epithelium. This transport is non-saturable and mainly occurs in the jejunum and ileum under conditions of adequate or high $\mathrm{Ca}$ intake ${ }^{(67)}$. When $\mathrm{Ca}$ intake is high, the sojourn time in the intestine is short and there is down-regulation of proteins involved in the transcellular pathway, which switches on the paracellular route ${ }^{(68)}$ (see Fig. 1).

\section{Hormonal effects}

\section{Calcitriol}

Calcitriol or 1,25-dihydroxycholecalciferol $\left(1,25(\mathrm{OH})_{2} \mathrm{D}_{3}\right)$ is the main stimulus for intestinal $\mathrm{Ca}$ absorption. It induces changes in the structure and function of intestinal epithelial cells, which enhance Ca transport across the intestine. Calcitriol acts through genomic and non-genomic pathways, after binding to a VDR. Most of the studies have been focused on the effect of calcitriol on the intestinal transcellular Ca pathway. It has been found that the expression or the activity of all molecules presumably involved in this route is increased by calcitriol in experimental animals and even in human subjects ${ }^{(69-72)}$. Recently, it has been shown in mice that a single administration of $1,25(\mathrm{OH})_{2} \mathrm{D}_{3}$ produced a 30-fold maximal increase in the ileal TRPV6 mRNA at $9 \mathrm{~h}$. Multiple dosing of $1,25(\mathrm{OH})_{2} \mathrm{D}_{3}$ increased the ileal TRPV6 to 200- to 600-fold, being the highest changes observed at the 3rd and 4th doses. TRPV6 protein levels were increased 1.5-fold throughout the duodenum and ileum after the $3 \mathrm{rd}$ and 4 th doses, while levels in the colon were increased after 


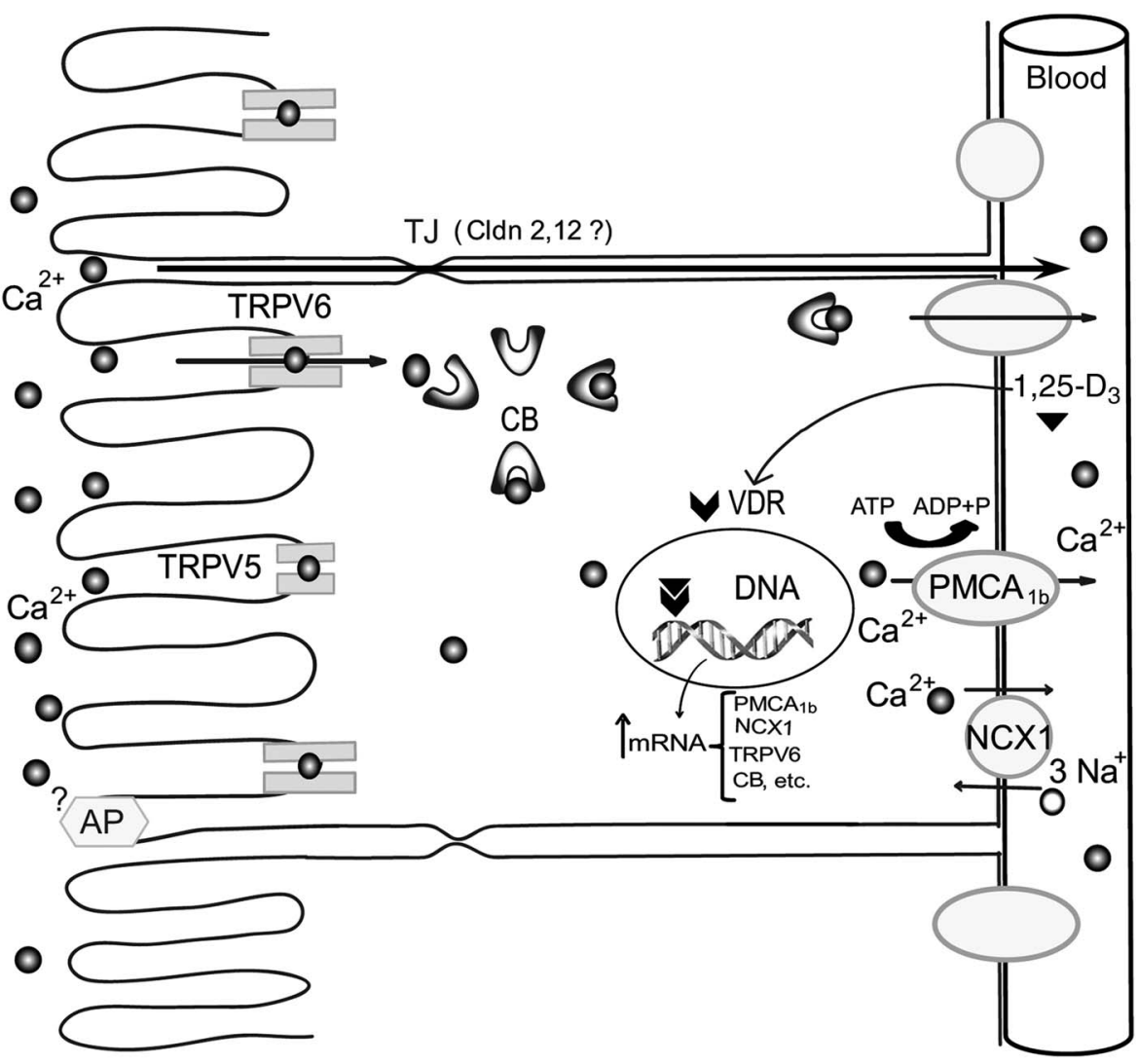

Fig. 1. Schematic model of transepithelial and paracellular calcium transport in the small intestine. The paracellular calcium pathway is carried out through tight junctions (TJ) by an electrochemical gradient (long arrow between cells). The transcellular calcium pathway consists of three steps: (1) apical entry of calcium through epithelial calcium channels TRPV5 and TRPV6 (the second one is the most abundant in intestine); (2) cytosolic diffusion bound to calbindins (CB); and (3) extrusion across the basolateral membranes by plasma membrane $\mathrm{Ca}^{2+}$-ATPase $\left(\mathrm{PMCA}_{1 \mathrm{~b}}\right)$ and $\mathrm{Na}^{+} / \mathrm{Ca}^{2+}$ exchanger (NCX1). Calcitriol $\left(1,25-\mathrm{D}_{3}\right)$ stimulates the individual steps of transcellular calcium transport. Calcitriol molecules bind to their nuclear receptors (vitamin $D$ receptors; VDR), and the complex $1,25-D_{3}-$ VDR interacts with specific DNA sequences inducing transcription and increasing the expression levels of PMCA ${ }_{1 b}, N C X 1, T R P V 6$ and CB. The real role of the intestinal alkaline phosphatase (AP) enzyme inintestinal calcium absorption has not been elucidated yet. Cldn, claudin.

the 4th dose. These changes in protein correlate with a high TRPV6 $\mathrm{mRNA}$ induction in the ileum at the same period ${ }^{(34)}$. The $1,25(\mathrm{OH})_{2} \mathrm{D}_{3}$-enhanced Ca transport in mice was reported to be inhibited by FGF-23 as well as Ca transport in the colon cancer Caco-2 cells. Fibroblast growth factor-23 (FGF-23) produced an abolishment of the enhanced transcellular active Ca fluxes in both models. Despite the Arrhenius plot indicating that FGF-23 decreased the potential barrier of paracellular $\mathrm{Ca}$ movement, FGF-23 was found to modestly down-regulate the $1,25(\mathrm{OH})_{2} \mathrm{D}_{3}$ enhanced paracellular Ca transport ${ }^{(73)}$. VDR-null mice adapt to pregnancy by up-regulating duodenal TRPV 6 and intestinal Ca absorption, which enables a rapid normalisation of bone mineral content. These mice lactate normally and fully restore bone mineral content after weaning. In other words, VDR seems not to be required for skeletal adaptation during pregnancy, lactation and after weaning ${ }^{(74)}$. In the elderly, there is an age-related decrease in $\mathrm{Ca}$ absorption and a higher $\mathrm{Ca}$ intake is needed. It seems that increasing $\mathrm{Ca}$ intake from dairy products and Ca-fortified foods is much better than supplements. The combination of vitamin D intake to $800 \mathrm{IU}(20 \mu \mathrm{g})$ daily together with a total $\mathrm{Ca}$ intake of $1000 \mathrm{mg}$ daily is a simple and inexpensive strategy that could reduce fractures in aged individuals by $30 \%{ }^{(75)}$.
Two studies have demonstrated that calcitriol increases paracellular fluxes across the intestine, mainly in the jejunum and ileum ${ }^{(76,77)}$. Fujita et al. ${ }^{(78)}$ have demonstrated that $1,25(\mathrm{OH})_{2} \mathrm{D}_{3}$ significantly increases claudin 2 and claudin 12 mRNA levels in Caco-2 cells. They have also shown that mRNA and protein levels for these proteins were lower at 12 weeks in the jejunum of VDR KO mice in comparison with wild-type mice, and small interfering RNA against these claudins decreased Ca permeability in the Caco-2 cells.

An intestinal calcistat has been hypothesised in order to explain vitamin D deficiency (VDD) with and without the clinical disease. Not all individuals with varying degree of VDD present secondary hyperparathyroidism and decreased bone mineral density (BMD). The intestinal calcistat would control Ca absorption, independently of parathyroid hormone (PTH) levels. A protein called $\mathrm{Ca}$ receptor $(\mathrm{CaR})$ would dampen the production of active vitamin D metabolites in intestinal cells and diminish transcellular $\mathrm{Ca}$ transport, but would increase the paracellular Ca pathway. This local adaptation would adjust the fractional Ca absorption (FCA) according to the body's needs. When this local adaptation fails due to decreased $\mathrm{Ca}$ intake, decreased 25-hydroxyvitamin $\mathrm{D}_{3}\left(25(\mathrm{OH}) \mathrm{D}_{3}\right)$, CaR mutation, the systemic adaptation comes into play. The systemic adaptations 
are an increase in PTH and in active vitamin D metabolites. A rise in PTH is the first indication of VDD with a decrease in BMD depending on the duration of VDD. Therefore, individuals with VDD with normal PTH and BMD should be called subclinical $\operatorname{VDD}^{(79)}$. The beneficial effect of vitamin D supplementation on this group of patients needs to be explored.

\section{Parathyroid hormone}

The action of PTH on intestinal $\mathrm{Ca}$ absorption occurs by the stimulation of renal CYP27B1 and, hence, increases $1,25(\mathrm{OH})_{2} \mathrm{D}_{3}$-dependent intestinal $\mathrm{Ca}$ absorption. Direct effects of PTH on Ca uptake by enterocytes from rat duodenum have been shown. PTH stimulates enterocyte $\mathrm{Ca}$ influx, which could be blocked by the $\mathrm{Ca}^{2+}$ channel antagonists verapamil and nitrendipine ${ }^{(80)}$. PTH/PTHrP receptors have been localised in intestinal epithelial cells along the villus ${ }^{(81)}$. PTH promotes nuclear effects such as a regulation of gene transcription and cell proliferation of enterocytes ${ }^{(82)}$. So far, a direct effect of PTH on the global process of intestinal $\mathrm{Ca}$ absorption has not been reported yet.

\section{Thyroid hormones}

Cross et al. ${ }^{(83)}$ have demonstrated that thyroid hormone and vitamin D have a cooperative effect on intestinal Ca transport. They have also observed that thyroid hormones increase the genomic action of calcitriol in the intestine. Kumar et al. ${ }^{(84)}$ have reported that hyperthyroid rats show larger Ca uptake by brush-border membrane vesicles and Ca efflux from the basolateral membranes of enterocytes than hypothyroid rats. The authors have also found that the $\mathrm{Ca}^{2+}$-ATPase activity is not altered by thyroid hormones, while NCX1 activity is highly increased.

\section{Growth hormone and insulin-like growth factor-1}

Growth hormone (GH) can promote intestinal Ca absorption, which would occur indirectly mediated through an activation of renal CYP27B1 and the increase of serum $1,25(\mathrm{OH})_{2} \mathrm{D}_{3}$ concentration $^{(85)}$. Fleet et al. ${ }^{(86)}$ have shown that $\mathrm{GH}$ treatment increases intestinal $\mathrm{Ca}$ absorption and duodenal $\mathrm{CB}_{9 \mathrm{k}}$ levels in aged rats without increasing serum $1,25(\mathrm{OH})_{2} \mathrm{D}_{3}$ levels. The effect of $\mathrm{GH}$ on $\mathrm{Ca}$ absorption is mediated through insulin-like growth factor-1 (IGF-1) and there is evidence that this effect does not depend on vitamin D signalling. Intestinal Ca absorption in adult men has been shown to be positively correlated with IGF-1 and the age-related declines in IGF-1 have a negative impact on $\mathrm{Ca}$ absorption, which could not be explained by a decrease in serum $1,25(\mathrm{OH})_{2} \mathrm{D}_{3}{ }^{(87)}$. Since the vitamin D-independent mechanism by which the GH/IGF-1 axis may regulate intestinal $\mathrm{Ca}$ absorption is not clear, this issue needs to be investigated.

\section{Oestrogen}

Oestrogen corrects the decline in the efficiency of intestinal Ca absorption at the onset of menopause, as suggested by cell culture studies ${ }^{(88)}$, but the mechanisms that underlie this effect remain unknown. Colin et al. ${ }^{(89)}$ have shown that oestrogen acts independently of $1,25(\mathrm{OH})_{2} \mathrm{D}_{3}$ in the intestine, while others suggest that oestrogen alters intestinal $\mathrm{Ca}$ absorption through the vitamin $\mathrm{D}$ endocrine system $^{(88)}$. Most of the oestrogen studies have been done in ovariectomised (OVX) animals. This ablation decreases endogenous oestrogen, but not totally since the adrenal androgens can be aromatised to oestrogen ${ }^{(90)}$. Oestrogen receptor (ER) $\alpha$ KO mice showed a decrease in duodenal TRPV6 mRNA expression, without changes in $\mathrm{CB}_{9 \mathrm{k}}$, $\mathrm{PMCA}_{1 \mathrm{~b}}$ and VDR levels. In contrast, ER $\beta$ KO mice did not alter the genes for intestinal $\mathrm{Ca}$ absorption. It seems that the genomic effects of oestrogen in mice are mainly mediated by ER $\alpha$. This idea should not be extrapolated to humans because it has been shown that in normal colon and cancer colon cells the subtype $\beta$ is the predominant form of the $\mathrm{ER}^{(91)}$. In OVX rats treated with oestradiol, van Abel et al. ${ }^{(92)}$ have found increased duodenal gene expression of TRPV5, TRPV6, CB $9 \mathrm{k}$ and PMCA $_{1 \mathrm{~b}}$. They used CYP27B1 KO mice to analyse the calcitriol dependency of the stimulatory effects of oestradiol on intestinal Ca absorption and demonstrated that the oestradiol treatment increased mRNA levels of duodenal TRPV6.

The effect of two dietary phyto-oestrogens (coumestrol and apigenin) as well as ipriflavone, a synthetic phyto-oestrogen, on $\mathrm{Ca}$ absorption has been studied in the human Caco-2 cell line ${ }^{(93)}$. A direct effect of these compounds on intestinal $\mathrm{Ca}$ absorption was not observed. These controversial results indicate that the mechanism(s) triggered by oestrogen in the intestine requires further investigation ${ }^{(94)}$.

\section{Glucocorticoids}

Osteoporosis is one of the most important side effects after long-term glucocorticoid (GC) treatments. Despite a reduced intestinal $\mathrm{Ca}$ absorption being part of the pathogenesis of GC-induced osteoporosis ${ }^{(95)}$, the mechanisms triggered by GC on the intestine are not clear. A short-term GC treatment in young animals does not affect the expression of genes involved in intestinal $\mathrm{Ca}$ absorption ${ }^{(96)}$, but a sustained dexamethasone suppresses mouse duodenal $\mathrm{CB}_{9 \mathrm{k}}$ expression through the $\mathrm{GC}$ receptor pathway ${ }^{(97)}$. It has been also reported that prednisolone for $10 \mathrm{~d}$ diminishes rat intestinal $\mathrm{Ca}$ absorption through a decreased expression of the active $\mathrm{Ca}$ transporters, which occurs independently of $1,25(\mathrm{OH})_{2} \mathrm{D}_{3}{ }^{(98)}$.

\section{Nutritional factors affecting intestinal calcium absorption}

\section{Dietary calcium}

Dietary $\mathrm{Ca}$ affects the composition of intestinal plasma membranes and alters intestinal $\mathrm{Ca}$ transport. All the genes involved in the transcellular pathway are enhanced by a low-Ca diet, which occurs by the activation of the vitamin $\mathrm{D}$ endocrine system $^{(19,55,99,100)}$. The increase in the expression and activity of the intestinal Ca pump and NCX1 caused by a Ca-deficient diet occurs in both mature and immature enterocytes. However, VDR levels are decreased by low-Ca diets, independently of the degree of cell differentiation ${ }^{(55)}$. We think that high levels of 
serum calcitriol provoked by low-Ca diets promote differentiation, which would produce cells more capable of expressing vitamin D-dependent genes required for $\mathrm{Ca}$ absorption. The activity of intestinal alkaline phosphatase (AP) is concomitantly increased by dietary $\mathrm{Ca}$ restriction, but a real role of this protein in intestinal $\mathrm{Ca}$ absorption cannot be discarded ${ }^{(55)}$. Benn et $a .^{(101)}$ have found that a low-Ca diet increases intestinal $\mathrm{Ca}$ absorption in wild-type, TRPV6 $\mathrm{KO}$ and $\mathrm{CB}_{9 \mathrm{k}} \mathrm{KO}$ mice. This study indicates that the active intestinal $\mathrm{Ca}$ absorption occurs in the absence of TRPV6 and $\mathrm{CB}_{9 \mathrm{k}}$, which challenges the dogma that both proteins are necessary for vitamin $\mathrm{D}$-induced active intestinal Ca transport. Probably, TRPV6 is not the rate-limiting factor in the transcellular pathway or another factor/s is/are involved in its absence to compensate partially its function.

We have also observed that a low-Ca diet increases the reactivity and availability of sulfhydryl groups from intestinal brush-border membrane proteins of chicks ${ }^{(102)}$. It is quite possible that the sulfhydryl status of the brush-border membrane proteins is involved in the vitamin D-dependent intestinal Ca absorption. With regard to the lipid composition, we have detected minor changes in the fatty acid content of the basolateral membrane, but the lipid fluidity of these membranes is highly increased by dietary Ca restriction ${ }^{(19)}$.

Recently, it has been reported that luminal Ca controls the intestinal $\mathrm{Ca}$ absorption through the modification of intestinal AP activity $^{(103)}$. Authors have found that luminal Ca concentration increases the activity of AP and simultaneously decreases percentage $\mathrm{Ca}$ absorption, acting as a minute-tominute regulatory mechanism of $\mathrm{Ca}$ entry.

Some studies have found an inverse association between Ca intake and adiposity ${ }^{(104-106)}$. However, not all studies have observed this relationship ${ }^{(107)}$. The mechanisms underlying these responses are not quite clear.

Most patients with idiopathic hypercalciuria show an increased intestinal $\mathrm{Ca}$ absorption. This has been demonstrated in studies using radiolabelled $\mathrm{Ca}$ and comparing the intestinal $\mathrm{Ca}$ absorption in patients with idiopathic hypercalciuria with that in normal subjects $^{(108)}$. One possible mechanism for the increased Ca absorption might be the highest levels of serum calcitriol found in these patients as compared with normal individuals ${ }^{(65)}$. Apparently, this response is independent of $\mathrm{Ca}$ intake and reflects an enhancement in active Ca transport by the intestine ${ }^{(109)}$.

With regard to the risk of kidney calculi formation in postmenopausal women, it is not clear if it is associated with $\mathrm{Ca}$ intake and vitamin D supplements. Haghighi et al. ${ }^{(110)}$ have shown that the administration of $1000 \mathrm{mg} / \mathrm{d}$ of dietary $\mathrm{Ca}$ and vitamin $\mathrm{D}$ had a weak association with the formation of kidney calculi (only $1.9 \%$ of fifty-three patients). Jackson et al. ${ }^{(111)}$ have reported that in a study with 36282 postmenopausal women treated with $1000 \mathrm{mg}$ of $\mathrm{Ca}$ and $400 \mathrm{IU}(10 \mu \mathrm{g})$ of vitamin $\mathrm{D} / \mathrm{d}$, a $17 \%$ higher rate of kidney calculi was shown in the treated group after 7 years of follow-up. In contrast, another study contradicted this result, suggesting no association between $\mathrm{Ca}$ and vitamin $\mathrm{D}$ consumption and kidney calculi formation $^{(112)}$. A low-Ca diet enhances the absorption of oxalate in the gut from normal individuals and kidney stone formers leading to an increase in urinary oxalate excretion, which has an important role in Ca stone formation ${ }^{(113,114)}$.
There is evidence that dietary Ca restriction is a risk factor for cancer incidence, particularly for colorectal cancer ${ }^{(115)}$. By contrast, a high intake of dairy products and $\mathrm{Ca}$ intake protects against the distal colon and rectal tumours as compared with the proximal colon and reduces the risk of colon cancer ${ }^{(116)}$. It is also quite possible that a low Ca intake contributes to the development of renal, gastric, pancreatic, ovarian, endometrial and lung cancer as well as multiple myeloma, but there is no conclusive evidence ${ }^{(117)}$.

Several studies have shown that a poor Ca intake is associated with an increased risk of breast cancer ${ }^{(118-120)}$. Vergne et al. ${ }^{(121)}$ have recently demonstrated that $\mathrm{Ca}$ intake is associated with a high DNA repair capacity level, which in turn decreases the development of breast cancer.

Observational studies have identified an inverse relationship between maternal $\mathrm{Ca}$ intake and the incidence of preeclampsia $^{(122,123)}$. When $\mathrm{Ca}$ supplements are administered during pregnancy, the incidence of pre-eclampsia and its consequences are reduced, including severe maternal morbidity and death ${ }^{(124)}$.

Several meta-analyses of randomised controlled trials have also indicated that $\mathrm{Ca}$ supplementation can lead to a small reduction in systolic and diastolic blood pressure; therefore, Ca supplements might be beneficial in patients with hypertension ${ }^{(125,126)}$. Varenna et $a l^{(127)}$ have confirmed an association between hypertension and osteoporosis. There is a higher prevalence of hypertension in women with osteoporosis and a higher prevalence of osteoporosis in women with hypertension. The authors suggest that a low dairy Ca intake could be associated with an increased risk of both diseases and be a possible pathogenic link between the two conditions.

It is well known that a reduced intestinal $\mathrm{Ca}$ absorption is a risk factor for osteoporosis. There is evidence that the use of Ca supplements decreases bone turnover by about $20 \%$, and this is associated with a reduction in bone loss in postmenopausal women $^{(128)}$. Low Ca intake was significantly associated with low BMD and increased risk of osteoporosis. However, the association between $\mathrm{Ca}$ and BMD was not consistently linear, and a sufficient vitamin D level might compensate for the negative influence of low Ca intake on bone ${ }^{(129)}$. Zhou et al. ${ }^{(130)}$ have observed that a higher cumulative $\mathrm{Ca}$ and vitamin $\mathrm{D}$ intake in adult women was associated with better bone health, as indicated by BMD at multiple sites.

\section{Other ions}

Aluminium. Several authors have reported that aluminium ions (Al), at pharmacological doses, are able to reduce intestinal Ca absorption via the vitamin D-dependent transcellular pathway in the small intestine of humans and animals ${ }^{(131-135)}$. Orihuela et al. ${ }^{(135)}$ have suggested that $\mathrm{Al}$ might interfere with $\mathrm{Ca}$ uptake by enterocytes through an effect on cell membranes. In addition, Al would decrease the intestinal glutathione (GSH) level affecting CB function and/or synthesis, which would lead to a reduced transcellular Ca absorption. Apparently, the inhibitory effect of Al varies according to thyroid hormone status ${ }^{(136)}$. In late pregnancy and mainly during the middle lactation of rats, $\mathrm{Al}$ has also been shown to reduce transcellular $\mathrm{Ca}$ absorption in the duodenum 
by interfering with the mechanisms of Ca transport partially mediated by a high serum level of oestrogen and prolactin ${ }^{(137)}$.

Phosphate. Severe dietary P deficiency is rare in humans and occurs only in conditions of severe starvation. Nevertheless, $\mathrm{P}$ deficiency can occur in alcoholics, patients with malabsorption syndromes, and those taking excessive amounts of Ca supplements ${ }^{(138)}$. Dietary $\mathrm{P}$ deficiency affects intestinal $\mathrm{Ca}$ absorption. Under this deficiency, serum $1,25(\mathrm{OH})_{2} \mathrm{D}_{3}$ content increases ${ }^{(139,140)}$ as well as the levels of $\mathrm{CB}$ and $\mathrm{CB}$ mRNA synthesis ${ }^{(141)}$. However, in some fashion, a low-P diet can stimulate $\mathrm{CB}$ formation and intestinal $\mathrm{Ca}$ absorption in the absence of an increased production of $1,25(\mathrm{OH})_{2} \mathrm{D}_{3}{ }^{(142)}$. The reactivity and availability of sulfhydryl groups of chick intestinal brush-border membranes have been also shown to increase by a low-P diet ${ }^{(102)}$, but it remains unknown whether this response is related to increased intestinal Ca absorption. Meyer et al. ${ }^{(143)}$ have demonstrated that chickens fed a low-P diet displayed an increase in intestinal VDR mRNA. The authors have reported that a complex regulation of VDR expression occurs in that low-P restriction enhances VDR mRNA levels, possibly via increased serum $1,25(\mathrm{OH})_{2} \mathrm{D}_{3}$.

Magnesium. For several decades, it has been known that there is interaction between $\mathrm{Ca}^{2+}$ and $\mathrm{Mg}^{2+}$ in the intestine, which varies throughout the intestine. $\mathrm{Mg}^{2+}$ has been found to inhibit $\mathrm{Ca}$ absorption primarily in the duodenum, whereas $\mathrm{Ca}$ inhibits $\mathrm{Mg}^{2+}$ transport in the ileum but not in the duodenum ${ }^{(144)}$. In studies of short-term uptake in rat duodenal mucosa, O'Donnell \& Smith ${ }^{(145)}$ have demonstrated that $\mathrm{Mg}^{2+}$ inhibited the timedependent uptake of $\mathrm{Ca}^{2+}$, but $\mathrm{Ca}^{2+}$ did not alter $\mathrm{Mg}^{2+}$ uptake. Increasing the $\mathrm{Mg}^{2+}$ concentration to $1.25 \mathrm{mmol} / \mathrm{l}$ decreased the mucosal-to-serosal flux of $\mathrm{Ca}$ by $50 \%$ and abolished net $\mathrm{Ca}$ absorption, mainly due to a depression in the paracellular pathway $^{(146)}$. In patients with idiopathic hypercalciuria and renal $\mathrm{Ca}$ stone disease, oral supplementation of $\mathrm{Mg}^{2+}$ has been shown to be favourable because it decreases $\mathrm{Ca}$ absorption and increases $\mathrm{Mg}^{2+}$ absorption, which may reduce risk factors for renal Ca stone formation ${ }^{(147)}$. By contrast, $\mathrm{Mg}^{2+}$ deficiency significantly increased enterocyte content of $\mathrm{Ca}^{(148)}$. The mechanism is difficult to understand because $\mathrm{Mg}^{2+}$ deprivation has been associated with a low production of $1,25(\mathrm{OH})_{2} \mathrm{D}_{3}$, the main stimulator of intestinal Ca absorption ${ }^{(149)}$. However, some studies contradict the previous data. Fine et al ${ }^{(150)}$ have found that increasing dietary $\mathrm{Mg}^{2+}$ had no effect on Ca absorption. Kosakai et al. ${ }^{(151)}$ have demonstrated in sheep that the apparent $\mathrm{Ca}$ absorption tended to increase when the dietary $\mathrm{Mg}^{2+}$ content was increased, which was accompanied without an alteration in the plasma $\mathrm{Ca}$ concentration and increased urinary $\mathrm{Ca}$ excretion. Bae et al. ${ }^{(152)}$ have shown that the consumption of seaweed $\mathrm{Ca}$ extract or inorganic calcium carbonate with $\mathrm{Mg}^{2+}$ oxide in OVX rats produced a similar intestinal $\mathrm{Ca}$ absorption, but only the seaweed $\mathrm{Ca}$ extract caused an increase in femoral BMD and strength in OVX rats. They concluded that seaweed $\mathrm{Ca}$ extract is a good $\mathrm{Ca}$ and $\mathrm{Mg}^{2+}$ source for improving bone health as compared with synthetic $\mathrm{Ca}^{2+}$ and $\mathrm{Mg}^{2+}$ supplementation.

\section{Lipids}

At present, the effects of dietary lipids on intestinal $\mathrm{Ca}$ absorption are not clear. Hessov et al. ${ }^{(153)}$ have demonstrated that low-fat-diets increase intestinal $\mathrm{Ca}$ absorption in nine patients with fat malabsorption. Steatorrhoea has been associated with an inhibition of intestinal Ca absorption ${ }^{(154)}$. Jewell et al. ${ }^{(155)}$ have found that both the paracellular $\mathrm{Ca}$ transport and transcellular Ca transport across monolayers of Caco-2 cells were significantly increased after exposure to conjugated linoleic acid. Murphy et al. ${ }^{(156)}$ have found that zona occludens-1, Ocldn, and Cldn-4 were all up-regulated while Cldn-1 was down-regulated by trans-10, cis-12-conjugated linoleic acid, which explains the increase in the paracellular route. However, they did not find any effect on genes involved in the transcellular pathway, which should be further explored. Fatty acids directly contribute to increasing intestinal Ca absorption via a cation exchange mechanism between cellular $\mathrm{H}^{+}$for luminal $\mathrm{Ca}^{2+}$ favoured by exchanger activity $2 \mathrm{H}^{+} / \mathrm{Ca}^{2+(157)}$. Fatty acids would increase the proliferation of colonic epithelial cells, producing a trophic effect on the mucosa; they contribute to increasing the absorptive surface ${ }^{(158,159)}$.

Recently, in high-fat diet-fed mice, Xiao et al. ${ }^{(160)}$ have found a marked decrease in the intestinal Ca absorption, which is accompanied by redox imbalance and increased duodenal oxidative damage, an effect that was avoided by lipoic acid or Ca supplementation. In addition, they have also shown that a high-fat diet down-regulates the gene expression of molecules involved in the transcellular pathway of intestinal $\mathrm{Ca}$ absorption, independently of calcitriol regulation. The authors think that the main cause for high-fat-diet-induced inhibitory intestinal $\mathrm{Ca}$ absorption is not Ca soap but duodenal oxidative stress.

\section{Carbohydrates}

Lactose is a disaccharide found in milk and dairy products that enhances Ca homeostasis, which should be beneficial for bone health ${ }^{(161)}$. It is well established that lactose stimulates the intestinal $\mathrm{Ca}$ absorption that seems to occur by passive transport in the small intestine ${ }^{(162)}$. Apparently, lactose promotes intestinal Ca absorption, independently of the vitamin D endocrine system. Natsuko et $a l .{ }^{(163)}$ have found that lactose alters intestinal AP in rats not only in a direct way, but also indirectly through a regulation of intestinal AP expression, mainly in the jejunum. Epilactose (a rare disaccharide in cows' milk) has been demonstrated to increase Ca transport in everted small-intestinal sacs by promoting the generation of SCFA and other organic acids ${ }^{(164)}$. Later on, the same group of investigators has found that the epilactose-mediated promotion of intestinal Ca absorption involves the paracellular route in the rat small intestine through the induction of myosin regulatory light chain phosphorylation via myosin light chain kinase and Rho-associated kinase ${ }^{(165)}$. They have also shown that epilactose improves intestinal Ca absorption in gastrectomised rats. They think that the resulting SCFA production by intestinal microbes is responsible for this effect, as well as the increase in the caecal mucosa area and the soluble Ca concentration ${ }^{(166)}$. 
Some sugar alcohols such as erythritol, xylitol, sorbitol, maltitol, palatinit or lactitol have been found to enhance Ca transport from rat small and large intestine epithelium in vitro. Differences in Ca transport were shown in different segments of the intestine, but not between the sugar alcohols tested ${ }^{(167)}$. Recently, Xiao et $a l .{ }^{(168)}$ have found that mannitol improves the absorption and retention of $\mathrm{Ca}^{2+}$ and $\mathrm{Mg}^{2+}$ in growing rats, an effect that occurs through the fermentation of mannitol in the caecum.

\section{Prebiotics}

The fortification of milk with milk $\mathrm{Ca}$ or $\mathrm{Ca}$ salts is among the strategies suggested to increase $\mathrm{Ca}$ intake or absorption or both, but the availability of $\mathrm{Ca}$ salts in milk has not been well characterised $^{(169)}$. In addition, several food ingredients such as fructo-oligosaccharides and caseinophosphopeptides (CPP) have been proposed as enhancers of the absorption of $\mathrm{Ca}$ from milk or other foods. Fructo-oligosaccharides belong to the group of non-digestible oligosaccharides (NDOs), which includes inulin, oligofructose and galacto-oligosaccharides. They can be digested by the colonic microflora, which produces SCFA that decreases intestinal $\mathrm{pH}$ and increases $\mathrm{Ca}$ solubility leading to an enhancement of paracellular and transcellular Ca transport ${ }^{(170,171)}$. It has also been suggested that NDOs increase active Ca transport by

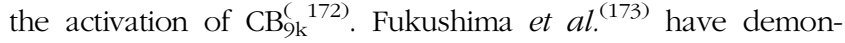
strated in rats that fructo-oligosaccharide consumption increases the gene expression of TRPV6 and $\mathrm{CB}_{9 \mathrm{k}}$ through the SCFA formed in the fermentation. The fibres formed mainly by inulin have positive chronic effects on Ca metabolism related to changes in the intestine, resulting in improvement of bone health ${ }^{(174)}$. In addition, galacto-oligosaccharides have also potential for improving mineral balance and bone properties ${ }^{(175)}$. With regard to $\mathrm{CPP}$, originating from casein digestion, it has been demonstrated that their addition to Ca-fortified milk increases intestinal Ca absorption in growing rats ${ }^{(176)}$, but the mechanisms involved in this response were not elucidated. Erba et al. ${ }^{(177)}$ have studied the influence of different four $\mathrm{CPP} / \mathrm{Ca}$ ratios and three mineral concentrations on the amount of passive Ca absorbed across the everted distal small intestine of rats. The positive effect was dependent on the relative amount of both species in the intestinal lumen, the ratio 15 being the most efficient at increasing mineral transport. Nevertheless, in a randomised cross-over trial undertaken in fifteen adults, no effect of CPP was found on intestinal Ca absorption ${ }^{(178)}$. Cosentino et al. ${ }^{(179)}$ have demonstrated that both intestinal human HT-29 and Caco- 2 cells have the ability to take up extracellular $\mathrm{Ca}$ under CPP stimulation. Recently, Colombini et al ${ }^{(180)}$ did not find effects of CPP on paracellular Ca absorption and on TRPV6 mRNA expression in intestinal human HT-29 and Caco-2 cell lines.

A recent study has shown that the daily intake of soluble maize fibre, a well-tolerated prebiotic fibre, increases short-term $\mathrm{Ca}$ absorption in adolescents consuming less than the recommended amounts of $\mathrm{Ca}^{(181)}$.

\section{Probiotics}

Probiotics are viable microbes that alter the microflora in a compartment of the host exerting beneficial health effects in this host ${ }^{(182)}$. Most probiotic products contain lactic acidproducing bacteria, which mainly belong to the genera Lactobacillus and Bifidobacterium. In growing rats, it has been demonstrated that probiotic yoghurt containing strains of Lactobacillus casei, L. reuteri and L. gasseri increase intestinal $\mathrm{Ca}$ absorption and bone mineral content ${ }^{(183)}$. Besides, it has been observed that in Caco-2 cells, the probiotic L. salivarius causes an increase in $\mathrm{Ca}^{2+}$ uptake ${ }^{(184)}$.

\section{Synbiotics}

Synbiotics are defined as products containing prebiotics and probiotics, in which the prebiotic compound favours the probiotic compound ${ }^{(182)}$. It has been shown in OVX rats that intestinal $\mathrm{Ca}$ absorption tended to be higher in the synbiotic group and was significantly higher in the prebiotic group in comparison with the control group ${ }^{(185)}$.

\section{Proteins}

Proteins are essential to bone, but the Ca-wasting effect of a high protein intake constitutes a point of debate. It has been known for many years that increasing dietary protein enhances urinary Ca either in human subjects or in rats ${ }^{(186)}$. The idea was that the additional $\mathrm{Ca}$ excretion was of skeletal origin as a result of buffering in bones the metabolic acid load imposed by higher protein intake ${ }^{(187)}$. The theory was that a high-protein diet, mainly meat, creates a higher acid load due to the high content of amino acids containing sulfur. This acid load cannot be neutralised by the kidneys and the body pulls $\mathrm{Ca}^{2+}$ from the skeleton to balance $\mathrm{pH}$ at the expense of bone, causing an enhancement of urinary $\mathrm{Ca}^{(188)}$. However, clinical studies have demonstrated that a short-term high-protein diet $(2 \cdot 1 \mathrm{~g} / \mathrm{kg})$ significantly increases the intestinal $\mathrm{Ca}$ absorption as compared with a medium-protein diet $(1 \mathrm{~g} / \mathrm{kg})$ and the increment in urinary $\mathrm{Ca}$ is quantitatively explained by an increase in intestinal $\mathrm{Ca}$ absorption efficiency ${ }^{(189)}$. The transcellular route, the paracellular pathway or a combination of both mechanisms of intestinal Ca absorption might be involved in response to high dietary protein. By using duodenal brush-border membrane vesicles, Gaffney-Stomberg et al. ${ }^{(190)}$ have demonstrated that the transcellular component of $\mathrm{Ca}$ absorption was accelerated in rats fed a high-protein diet, which was due to an enhancement in maximum velocity, without affecting the Michaelis-Menten constant. However, they did not study whether the gene or protein expression of the molecules involved in the transcellular pathway was modified. They did not find increased bone resorption or changes in serum PTH and calcitriol levels.

Since more research is necessary to resolve the protein debate, it has been suggested not to reduce the protein intake below the dietary reference intake because it could be detrimental to bone health, especially in old individuals ${ }^{(191)}$, and protein intakes and balance of different protein sources with a variety of different foods constitutes appropriate dietary advice ${ }^{(192)}$.

\section{Black tea}

Black tea (Camellia sinensis) is a medicinal plant with a rich flavonoid content and a plethora of health-promoting effects ${ }^{(193,194)}$. 
Das et al. ${ }^{(195)}$ have studied the ability of black tea extract as a suitable alternative adjunct for Ca supplementation in treating an OVX rat model of early osteoporosis. The results suggest that black tea could stimulate intestinal $\mathrm{Ca}$ absorption, which is associated with an increased activity of AP and $\mathrm{Ca}^{2+}$-ATPase. Black tea's effectiveness in maintaining bone health was detected to be similar to $17 \beta$-oestradiol. Therefore, this study suggests that a simultaneous use of black tea is promising as a prospective candidate for adjunctive therapies for $\mathrm{Ca}$ supplementation in the early stage of menopausal bone changes.

\section{Coffee}

Coffee drinking is a popular habit worldwide. It is consumed in considerable amounts every day. Caffeine, a methylxanthine present in coffee, has been considered to be responsible for an increased risk of osteoporosis in coffee drinkers ${ }^{(196,197)}$. At present, data are inconsistent ${ }^{(198-200)}$, hence, the effect of caffeine on intestinal $\mathrm{Ca}$ absorption is not well established. It has been demonstrated in rats that intestinal $\mathrm{Ca}$ absorption is stimulated by the increase in $1,25(\mathrm{OH})_{2} \mathrm{D}_{3}$ production after chronic administration of caffeine ${ }^{(201)}$. In addition, urinary and faecal excretion is also increased. In postmenopausal osteoporotic women, a coffee intake in excess of $1000 \mathrm{ml}$ could induce an extra $\mathrm{Ca}$ loss of $1.6 \mathrm{mmol} \mathrm{Ca} / \mathrm{d}$, while $1-2$ cups of coffee/d would have little impact on Ca balance ${ }^{(202)}$. Metabolic balance studies show a weak negative effect of caffeine on the efficiency of intestinal Ca absorption. However, the effect of caffeine is small enough to be fully offset by 1-2 tablespoons $(15-30 \mathrm{ml})$ of $\mathrm{milk}^{(138)}$. A recent study in OVX rats has shown that low to moderate caffeine intake may exert some beneficial effects on the skeleton, increasing bone mineralisation, and improving the strength and structure of cancellous bone and the mechanical properties of compact bone; however, it did not cause any significant effect in rats with normal oestrogen levels ${ }^{(203)}$. The continuous debate has weakened interest in the study of coffee as a risk factor for osteoporosis, which has been reinforced by the non-inclusion of coffee in the list of risk factors in the predictive scale for fracture informed by the $\mathrm{WHO}^{(204)}$. The understanding of physiological effects of coffee consumption is difficult because of the vast array of components included in the brewed product and the varied effects of each compound. Recently, an unfavourable effect of trigonelline, an alkaloid present in coffee, has been demonstrated on bone mechanical properties in oestrogen-deficient rats, but not in control rats ${ }^{(205)}$. It is quite possible that the effects on intestinal $\mathrm{Ca}$ absorption and the Ca economy by caffeine or other bioactive compounds present in coffee depend on the amount and frequency of coffee intake. This is another issue that merits to be more investigated due to the considerable number of coffee drinkers and the rising life expectancy that will increase bone disorders in the next years.

\section{Pharmacological compounds altering intestinal calcium absorption}

Almost two decades ago, we reported that the intactness of the steady-state levels of intestinal glutathione (GSH) seemed to be critical for Ca absorption. By using DL-buthionine- $(S, R)$ sulfoximine (BSO), a specific inhibitor of $\gamma$-glutamylcysteine synthetase, we have shown that the Ca transfer from lumen to blood in vitamin D-supplemented chicks was inhibited, an effect that did not occur in vitamin D-deficient chicks. At that time we concluded that the effects of BSO on intestinal $\mathrm{Ca}$ absorption were dependent on the vitamin D status of the animal. One explanation that we gave was that GSH depletion might increase the reactive oxygen species and other substances that could deteriorate intestinal Ca absorption ${ }^{(19)}$. Since intestinal AP was one of the best candidates to suffer oxidative stress $^{(206)}$, we later studied the effect of BSO on the activity of this enzyme in chicks fed a commercial diet. In fact, the AP activity declined after BSO treatment, which was dose and time dependent. The effect occurred either in vivo or in vitro but was not direct; it was first necessary to deplete GSH in order to produce free hydroxyl radicals and an increment in the protein carbonyl content. The reversibility of the BSO effect was proved by the addition of GSH monoester to the duodenal loop ${ }^{(207)}$.

Menadione (MEN) is another pharmacological compound that alters chick intestinal $\mathrm{Ca}$ absorption. It is a quinone that is clinically relevant because of its anti-tumour properties ${ }^{(208)}$ and its use in the treatment of osteoporosis ${ }^{(209)}$. MEN metabolism involves redox cycling, resulting in the release of various reactive oxygen species including free hydroxyl radicals ${ }^{(210)}$. We have demonstrated $30 \mathrm{~min}$ after a single large dose of MEN that the intestinal $\mathrm{Ca}$ absorption was inhibited, which lasted for $9 \mathrm{~h}$. The inhibition affected the transcellular pathway as judged by the inhibition of $\mathrm{Ca}^{2+}$ pump activity, the main protein involved in $\mathrm{Ca}^{2+}$ extrusion from the enterocyte to the lamina propria. Intestinal AP activity was also inhibited, but not that from other brush-border membrane enzymes. GSH depletion, enhancement in the protein carbonyl content as well as the appearance of free hydroxyl radicals were indications that MEN caused oxidative stress provoking deleterious consequences on intestinal $\mathrm{Ca}$ absorption. The oral administration of $\mathrm{GSH}$ monoester prevented the inhibition of intestinal $\mathrm{Ca}$ absorption and the GSH deprivation produced by $\mathrm{MEN}^{(211)}$. As mitochondria are the major source of reactive oxygen species $^{(212)}$, we have investigated the role of these organelles in the inhibition of the intestinal $\mathrm{Ca}$ absorption caused by MEN. The quinone produced mitochondrial dysfunction as shown by inhibition of enzymes from Krebs' cycle, DNA fragmentation, release of cytochrome c, alteration of membrane potential and enhancement of $\mathrm{Mn}^{2+}$-superoxide dismutase activity. The mitochondrial dysfunction would be a consequence of mitochondrial GSH depletion, which would alter the membrane permeability triggering the release of apoptotic molecules leading to DNA fragmentation. The oxidant effects would alter the transcellular $\mathrm{Ca}$ pathway affecting the global process of intestinal Ca absorption ${ }^{(213)}$. Since the flavonol quercetin has antioxidant properties $^{(214)}$, we have studied the ability of quercetin to protect the chick intestine against the inhibition of intestinal Ca absorption caused by MEN. Effectively, quercetin abrogated the inhibitory effect of MEN on chick intestinal Ca absorption through the restoration of intestinal redox state, blockage of alterations in the mitochondrial membrane permeability, and abolition of the FasL/Fas/caspase-3 signalling pathway activation ${ }^{(215)}$. 
In addition, the hormone melatonin (MEL) was also able to restore chick intestinal Ca absorption inhibited by MEN. MEL is known as a direct scavenger of free radicals with the ability to remove singlet oxygen, the superoxide anion radical and hydroperoxide. It has also an indirect antioxidant action through a modulation of antioxidant enzyme activities. MEL by itself did not alter intestinal Ca absorption and other variables influencing that process. The MEL protective mechanism seems to be switched on under oxidative stress conditions produced by MEN, leading cells to the normal redox status. MEL administration after MEN injection returned rapidly the intestinal GSH and protein carbonyl contents to control values as well as the SOD and CAT activities. Concomitantly, intestinal $\mathrm{Ca}$ absorption went up to normal values, suggesting that the restoration of redox status of the gut by MEL allowed the recovering of the intestinal capability to absorb the cation properly. MEL not only normalised the redox status of the enterocytes but also rescued the epithelial cells from MEN-induced apoptosis ${ }^{(216)}$. Therefore, MEL could be a potential drug of choice for the treatment of impaired intestinal Ca absorption caused by oxidative stress and exacerbated apoptosis, which occurs in certain pathophysiological conditions (ageing, coeliac disease, intestinal bowel disease, cancer and others) or after intake of drugs causing oxidation.

We have also shown that a single high concentration of sodium deoxycholate (NaDOC) inhibits intestinal Ca absorption through a down-regulation of proteins involved in the transcellular pathway, as a consequence of triggering oxidative stress and mitochondria-mediated apoptosis ${ }^{(217)}$. This inhibitory effect on intestinal $\mathrm{Ca}$ absorption produced by $\mathrm{NaDOC}$ has been shown to be abolished by the concomitant use of the antioxidant quercetin, which clearly indicates that the response of NaDOC was mediated by the oxidative stress. Deoxycholic acid or its salt, NaDOC, is the major secondary bile acid in humans and is toxic in high concentrations causing liver damage during cholestasis and acting as a promoter of colon cancer in experimental animals ${ }^{(218)}$. It is well known that its concentration varies according to the diet; a high-fat diet is associated with an increased secretion of $\mathrm{NaDOC}^{(219)}$. This bile salt perturbs the membrane structures by alteration of membrane microdomains and decreases the transepithelial electrical resistance in the Caco-2 cell line through reactive oxygen species generation and other signalling mechanisms ${ }^{(220,221)}$. Therefore, the tight junctions constitute another target of NaDOC in the intestine, suggesting that the paracellular pathway of intestinal $\mathrm{Ca}$ absorption might be also affected by this bile salt. Based on the knowledge that a minor bile acid, ursodeoxycholic acid (UDCA), has beneficial effects of protection against cytotoxicity due to more toxic bile acids, we have tried to ascertain the potentiality of UDCA to prevent the inhibition of intestinal $\mathrm{Ca}$ absorption caused by NaDOC. In addition, we have studied the effects of UDCA alone on intestinal $\mathrm{Ca}$ absorption either in chicks or rats. The data have shown that UDCA not only prevented the inhibition of intestinal $\mathrm{Ca}$ absorption caused by NaDOC either in chicks or rats, but also UDCA alone enhanced that process. This was an unpredictable finding, which together with the previous data indicate that NaDOC is a bad whereas UDCA is a good bile acid for intestinal $\mathrm{Ca}$ absorption. The interesting point is that the combination of both bile acids neutralises the response of each other, probably because UDCA protects the intestine against the GSH depletion and protein carbonyl increment produced by NaDOC. Both NaDOC and UDCA altered protein and gene expression of molecules involved in the transcellular pathway of intestinal $\mathrm{Ca}$ absorption, but in the opposite way. NaDOC decreased the protein expression of PMCA1b, NCX1and CB, whereas UDCA increased the protein expression of all of them. The expression of these molecules was identical to those from the control group when the combined treatment was used. The gene expression of pmca1b, ncx 1 and $c b$ was increased by UDCA and UDCA + NaDOC. In contrast, NaDOC decreased the gene expression of pmca1b and $c b$ without modifying that of $n c x 1$. UDCA also increased the protein and gene expression of VDR, which suggests that VDR is involved in the enhancement of intestinal $\mathrm{Ca}$ absorption produced by $\mathrm{UDCA}^{(222)}$. The relationship between UDCA and VDR is not surprising because it has been demonstrated that VDR also binds bile acids ${ }^{(223,224)}$ and the increase in the cathelicidin expression in biliary epithelial cells from human liver caused by UDCA is mediated by VDR activation, an effect that is blunted by a small interfering RNA strategy ${ }^{(225)}$.

There are conflicting data with regard to the effects of proton pump inhibitors and osteoporotic fracture risk. Presumably, they increase the risk through hypochlorhydria and decreased FCA. Hansen et al. ${ }^{(226)}$ have evaluated the effect of proton pump inhibitor therapy on FCA using the dual stable isotope method. Participants underwent three $24 \mathrm{~h}$ FCA studies; two of them were accomplished 1 month apart to establish the baseline of FCA, the third one was after taking omeprazole $(40 \mathrm{mg} / \mathrm{d}$ for $30 \mathrm{~d})$. The data revealed that age, gastric $\mathrm{pH}$, serum omeprazole levels, adherence to omeprazole and 25-hydroxyvitamin D levels were not related to changes in FCA between visits 2 and 3 . The level of serum $1,25(\mathrm{OH})_{2} \mathrm{D}_{3}$ was the only variable associated with the change in FCA between visits 2 and 3. More studies are necessary to elucidate the mechanisms by which proton pump inhibitors increase osteoporotic fracture risk.

Wahl et al. ${ }^{(227)}$ have demonstrated reduced FCA in patients under anticonvulsant treatment. The possible mechanism underlying this process is complex. It has been demonstrated that phenytoin and carbamazepine inhibit active Ca transport from the apical to the basolateral side of Caco- 2 cells under physiological Ca conditions and vitamin D improves the antiepileptic drug-induced decrease in Ca permeability ${ }^{(22)}$.

Restraint stress significantly down-regulates the mRNA expressions of TRPV 6 and $\mathrm{Ca}_{\mathrm{v}} 1.3, \mathrm{CB}-\mathrm{D}_{9 \mathrm{k}}$, and $\mathrm{PMCA}_{1 \mathrm{~b}}$, but not the expression of TRPV5 or NCX1. In contrast, the mRNA expressions of paracellular genes, ZO-1, occludin and claudin-3, are not modified by restraint stress. Since several antidepressant or anxiolytic drugs alleviate stress-induced depressive and anxiety symptoms, Charoenphandhu et al. ${ }^{(229)}$ have hypothesised that these drugs might also enhance Ca transporter gene expression in stressed rats. In fact, a 4-week daily administration of $10 \mathrm{mg} / \mathrm{kg}$ fluoxetine, $10 \mathrm{mg} / \mathrm{kg}$ reboxetine or $10 \mathrm{mg} / \mathrm{kg}$ venlafaxine differentially increased the duodenal $\mathrm{Ca}$ transporter genes in stressed rats, whereas $2 \mathrm{mg} / \mathrm{kg}$ diazepam had no such effect. These findings might be applied to help ameliorate 
the stress-induced bone loss and osteoporosis by restoring intestinal Ca absorption.

Octyphenol, a degradative product used to produce rubber, pesticides and paints, and bisphenol A (BPA), an organic compound used for manufacturing polycarbonate plastic and epoxy resins, are known as endocrine disruptors. The effect of both on serum Ca levels and expressions of Ca transport genes in the duodenum and kidney was studied in pregnant mice. Either octyphenol or BPA decreased serum Ca levels. Both drugs decreased the levels of TRPV 5 and $\mathrm{CB}_{9 \mathrm{k}}$ in the kidney and the levels of TRPV6 in the duodenum. Gene expression and protein expression of $\mathrm{CB}_{9 \mathrm{k}}$ were decreased in the duodenum by BPA but increased by octyphenol at high doses. These results indicate that decreased serum Ca levels caused by these disruptors might be a consequence of the alteration in the expression of genes related to Ca transport ${ }^{(230)}$.

\section{Gene $\times$ diet interactions influence intestinal calcium absorption}

Dietary Ca restriction increases the efficiency of intestinal $\mathrm{Ca}$ absorption, but the impact of genetics on this adaptive response is not clear. In humans, the efficiency of intestinal $\mathrm{Ca}$ absorption varies from 7 to $75 \%{ }^{(231)}$. The large variation is probably owing to the influence of multiple physiological factors (for example, growth, pregnancy, lactation, ageing) and environmental variables (for example, dietary Ca intake, vitamin D). Little information is available for the impact of genetics on the efficiency of intestinal $\mathrm{Ca}$ absorption and the adaptive up-regulation of $\mathrm{Ca}$ absorption to a low dietary $\mathrm{Ca}$ intake. Two laboratories have studied the efficiency of intestinal $\mathrm{Ca}$ absorption in different mice and have found that it is higher in $\mathrm{C} 3 \mathrm{H} / \mathrm{HeJ}$ mice in comparison with $\mathrm{C} 57 \mathrm{BL} / 6 \mathrm{~J}$ mice, which suggests that genetic background might influence this trait ${ }^{(232)}$. In addition, racial differences in the ability of adolescent girls to increase $\mathrm{Ca}$ absorption efficiency during a low $\mathrm{Ca}$ intake also indicate that this adaptive response has a genetic component ${ }^{(233,234)}$ In agreement with this concept, adolescent black girls have been shown to exhibit higher intestinal $\mathrm{Ca}$ absorption as compared with white girls ${ }^{(235)}$, and this may contribute to the higher bone deposition found in black girls ${ }^{(236)}$.

Replogle et al. ${ }^{(237)}$ have examined eleven inbred lines of mice fed on defined diets containing either high or low Ca concentration from weaning to 12 weeks of age. The authors have shown that genetic variation and gene $\times$ diet interactions affect not only the active intestinal $\mathrm{Ca}$ absorption, but also its relationship to bone. These interactions are partially explained by variations in the traditional cellular mediators (i.e. TRPV6, $\mathrm{CB}_{9 \mathrm{k}}, \mathrm{PMCA}_{1 \mathrm{~b}} \mathrm{mRNA}$ ) and in the main hormonal regulator, $1,25(\mathrm{OH})_{2} \mathrm{D}_{3}$, of intestinal $\mathrm{Ca}$ absorption. This field is relatively new, hence many efforts are required to bring more light for the understanding of this knowledge.

\section{Conclusions}

$\mathrm{Ca}^{2+}$ is an ion involved in multiple physiological functions. Absorption through the intestinal epithelium is a complex process regulated by an intricate network of hormones and nutritional factors. At present, the Western diet model adopted is poor in Ca content and at the same time interferes with the proper absorption of the cation. Some diseases such as osteoporosis, hypertension and cancer are associated with dietary $\mathrm{Ca}$ restriction. Current recommendations are to obtain $\mathrm{Ca}$ from the diet in preference to supplements since dietary $\mathrm{Ca}$ intake has not been associated with the adverse effects of supplements, probably because $\mathrm{Ca}$ is provided in smaller boluses absorbed more slowly ${ }^{(238)}$. Milk and dairy products are the best sources of $\mathrm{Ca}$. There have been advances in food industry attempts to compensate for the $\mathrm{Ca}$ shortage through the introduction of prebiotics and probiotics in the basic diet. Certain dietary habits such as an increased protein intake remain a point of debate. It is important to take into account that alterations in the redox state of the intestinal epithelium produced by some medications such as MEN, BSO and UDCA also modify the intestinal $\mathrm{Ca}$ absorption. Therefore, intestinal $\mathrm{Ca}$ absorption must be carefully attended, so it is necessary to consider not only the intake, but also possible interactions with other ions, the genetic background, the effect of diet and the use of certain medications. Health professionals should be aware of this knowledge in order to develop nutritional or medical strategies to stimulate the efficiency of intestinal $\mathrm{Ca}$ absorption and to prevent diseases.

\section{Acknowledgements}

This work was supported by grants from the Consejo Nacional de Investigaciones Científicas y Tecnológicas (CONICET; PIP 2013-15) and SECYT (UNC), Argentina. N. T. T., A. C. and V. R. are members of Investigator Career from CONICET. V. A. is a recipient of a fellowship from CONICET.

There are no conflicts of interest to declare.

\section{References}

1. Ma J, Johns RA \& Stafford RS (2007) Americans are not meeting current calcium recommendations. Am J Clin Nutr 85, 1361-1366.

2. Eisner V, Csordás G \& Hajnóczky G (2013) Interactions between sarco-endoplasmic reticulum and mitochondria in cardiac and skeletal muscle - pivotal roles in $\mathrm{Ca}^{2+}$ and reactive oxygen species signaling. J Cell Sci 15, 2965-2978.

3. Szadujkis-Szadurska K, Szadujkis-Szadurski R, SzadujkisSzadurski L, et al. (2010) The role of calcium in modulating the reactivity of the smooth muscle cells during ischemia/ reperfusion. Part 1. Postepy Hig Med Dosw 15, 188-194.

4. Koklic T, Majumder R \& Lentz BR (2014) $\mathrm{Ca}^{2+}$ switches the effect of PS-containing membranes on factor Xa from activating to inhibiting: implications for initiation of blood coagulation. Biochem J 462, 591-601.

5. Chaigne-Delalande B \& Lenardo MJ (2014) Divalent cation signaling in immune cells. Trends Immunol 35, 332-344.

6. Zemel MB (2001) Calcium modulation of hypertension and obesity: mechanisms and implications. J Am Coll Nutr 20, 428S-435S

7. Appel LJ, Brands MW, Daniels SR, et al. (2006) Dietary approaches to prevent and treat hypertension: a scientific statement from the American Heart Association. Hypertension 47, 296-308. 
8. Laraichi S, Parra P, Zamanillo R, et al. (2013) Dietary supplementation of calcium may counteract obesity in mice mediated by changes in plasma fatty acids. Lipids $\mathbf{4 8}$, 817-826.

9. Bartlett PJ, Gaspers LD, Pierobon N, et al. (2014) Calciumdependent regulation of glucose homeostasis in the liver. Cell Calcium 55, 306-316.

10. Lin J, Manson JE, Lee IM, et al. (2007) Intakes of calcium and vitamin D and breast cancer risk in women. Arch Intern Med 167, 1050-1059.

11. Ju J, Kwak Y, Hao X, et al. (2012) Inhibitory effects of calcium against intestinal cancer in human colon cancer cells and $A p C^{\mathrm{Min} /+}$ mice. Nutr Res Pract 6, 396-404.

12. Williams CD, Whitley BM, Hoyo C, et al. (2012) Dietary calcium and risk for prostate cancer: a case-control study among US veterans. Prev Chronic Dis 9, 110125.

13. Merritt MA, Cramer DW, Vitonis AF, et al. (2013) Dairy foods and nutrients in relation to risk of ovarian cancer and major histological subtypes. Int J Cancer 132, 1114-1124.

14. Fleet JC \& Schoch RD (2010) Molecular mechanisms for regulation of intestinal calcium absorption by vitamin $\mathrm{D}$ and other factors. Crit Rev Clin Lab Sci 47, 181-195.

15. Bronner F (1998) Calcium absorption - a paradigm for mineral absorption. J Nutr 128, 917-920.

16. Wasserman RH (2004) Vitamin D and the dual processes of intestinal calcium absorption. J Nutr 134, 3137-3139.

17. Marcus CS \& Lengemann FW (1962) Absorption of $\mathrm{Ca}^{45}$ and $\mathrm{Sr}^{85}$ from solid and liquid food at various levels of the alimentary tract of the rat. $J$ Nutr $77,155-160$.

18. Wali RK, Baum CL, Sitrin MD, et al. (1990) 1,25(OH) 2 vitamin $\mathrm{D}_{3}$ stimulates membrane phosphoinositide turnover, activates protein kinase $\mathrm{C}$, and increases cytosolic calcium in rat colonic epithelium. J Clin Invest 85, 1296-1303.

19. Tolosa de Talamoni N (1996) Calcium and phosphorous deficiencies alter the lipid composition and fluidity of intestinal basolateral membranes. Comp Biochem Physiol A Physiol 115, 309-315.

20. Nordin BE, Need AG, Morris HA, et al. (2004) Effect of age on calcium absorption in postmenopausal women. $\mathrm{Am} \mathrm{J}$ Clin Nutr 80, 998-1002.

21. O'Brien KO, Nathanson MS, Mancini J, et al. (2003) Calcium absorption is significantly higher in adolescents during pregnancy than in the early postpartum period. Am J Clin Nutr 78, 1188-1193.

22. Prentice A (2000) Maternal calcium metabolism and bone mineral status. Am J Clin Nutr 71, 1312S-1316S.

23. Zhu Y, Goff JP, Reinhardt TA, et al. (1998) Pregnancy and lactation increase vitamin D-dependent intestinal membrane calcium adenosine triphosphatase and calcium binding protein messenger ribonucleic acid expression. Endocrinology 139, 3520-3524.

24. Liesegang A, Riner K \& Boos A (2007) Effects of gestation and lactation on vitamin D receptor amounts in goats and sheep. Domest Anim Endocrinol 33, 190-202.

25. Wongdee K, Teerapornpuntakit J, Siangpro C, et al. (2013) Duodenal villous hypertrophy and upregulation of claudin-15 protein expression in lactating rats. J Mol Histol 44, 103-109.

26. Teerapornpuntakit J, Klanchui A, Karoonuthaisiri N, et al. (2014) Expression of transcripts related to intestinal ion and nutrient absorption in pregnant and lactating rats as determined by custom-designed cDNA microarray. Mol Cell Biochem 391, 103-116.

27. van Abel M, Hoenderop JG \& Bindels RJ (2005) The epithelial calcium channels TRPV5 and TRPV6: regulation and implications for disease. Naunyn Schmiedebergs Arch Pharmacol 371, 295-306.
28. Bianco SD, Peng JB \& Takanaga H (2007) Marked disturbance of calcium homeostasis in mice with targeted disruption of the Trpv6 calcium channel gene. J Bone Miner Res 22, 274-285.

29. Cui M, Li Q, Johnson R, et al. (2012) Villin promoter-mediated transgenic expression of transient receptor potential cation channel, subfamily V, member 6 (TRPV6) increases intestinal calcium absorption in wild-type and vitamin $\mathrm{D}$ receptor knockout mice. J Bone Miner Res 27, 2097-2107.

30. Den Dekker E, Hoenderop JG, Nilius B, et al. (2003) The epithelial calcium channels, TRPV5 \& TRPV6: from identification towards regulation. Cell Calcium 33, 497-507.

31. Hoenderop JG, Voets T, Hoefs S, et al. (2003) Homo- and heterotetrameric architecture of the epithelial $\mathrm{Ca}^{2+}$ channels TRPV5 and TRPV6. EMBO J 17, 776-785.

32. Hoenderop JG, Vennekens R \& Müller D (2001) Function and expression of the epithelial $\mathrm{Ca}^{2+}$ channel family: comparison of mammalian ECaC1 and 2. J Physiol 15, 747-761.

33. Walters JR, Balesaria S, Chavele KM, et al. (2006) Calcium channel TRPV6 expression in human duodenum: different relationships to the vitamin $\mathrm{D}$ system and aging in men and women. J Bone Miner Res 21, 1770-1777.

34. Chow EC, Quach HP, Vieth R, et al. (2013) Temporal changes in tissue $1 \alpha, 25$-dihydroxyvitamin $\mathrm{D}_{3}$, vitamin $\mathrm{D}$ receptor target genes, and calcium and PTH levels after $1,25(\mathrm{OH})_{2} \mathrm{D}_{3}$ treatment in mice. Am J Physiol Endocrinol Metab 304, E977-E989.

35. Tolosa de Talamoni N, Pérz A \& Alisio A (1998) Effect of cholecalciferol on intestinal epithelial cells. Trends Comp Biochem Physiol 5, 179-185.

36. Schwaller B (2010) Cytosolic $\mathrm{Ca}^{2+}$ buffers. Cold Spring Harb Perspect Biol 2, a004051.

37. Cheung WT, Richards DE \& Rogers JH (1993) Calcium binding by chick calretinin and rat calbindin D28k synthesised in bacteria. Eur J Biochem 15, 401-410.

38. Nägerl UV, Novo D, Mody I, et al. (2000) Binding kinetics of calbindin- $\mathrm{D}_{28 \mathrm{k}}$ determined by flash photolysis of caged $\mathrm{Ca}^{2+}$. Biophys J 79, 3009-3018.

39. Choi KJ, Cho DS, Kim JY, et al. (2011) Ca-induced Ca release from internal stores in INS-1 rat insulinoma cells. Korean J Physiol Pharmacol 15, 53-59.

40. Bellido T, Huening M, Raval-Pandya M, et al. (2000) Calbindin- $\mathrm{D}_{28 \mathrm{k}}$ is expressed in osteoblastic cells and suppresses their apoptosis by inhibiting caspase-3 activity. J Biol Chem 275, 26328-26332.

41. Merico V, de Barboza GD, Vasco C, et al. (2008) A mitochondrial mechanism is involved in apoptosis of Robertsonian mouse male germ cells. Reproduction 135, 797-804.

42. Rodriguez V, Diaz de Barboza G, Ponce R, et al. (2010) Spermatocyte apoptosis, which involves both intrinsic and extrinsic pathways, explains the sterility of Graomys griseoflavus $\times$ Graomys centralis male hybrids. Reprod Fertil Dev 22, 478-488.

43. Lambers TT, Mahieu F, Oancea E, et al. (2006) CalbindinD28K dynamically controls TRPV5-mediated $\mathrm{Ca}^{2+}$ transport. EMBO J 12, 2978-2988.

44. Airaksinen MS, Eilers J \& Garaschuk O (1997) Ataxia and altered dendritic calcium signaling in mice carrying a targeted null mutation of the calbindin D28k gene. Proc Natl Acad Sci U S A 18, 1488-1493.

45. Christakos S, Dhawan P, Ajibade D, et al. (2010) Mechanisms involved in vitamin D mediated intestinal calcium absorption and in non-classical actions of vitamin D. J Steroid Biochem Mol Biol 121, 183-187.

46. Hwang I, Yang H, Kang HS, et al. (2013) Alteration of tight junction gene expression by calcium- and vitamin D-deficient diet in the duodenum of calbindin-null mice. Int J Mol Sci 14, 22997-23010. 
47. Schatzmann HJ (1966) ATP-dependent $\mathrm{Ca}^{++}$-extrusion from human red cells. Experientia 15, 364-365.

48. Barley NF, Howard A, O'Callaghan D, et al. (2001) Epithelial calcium transporter expression in human duodenum. $A m \mathrm{~J}$ Physiol Gastrointest Liver Physiol 280, G285-G290.

49. Peng JB, Chen XZ, Berger UV, et al. (1999) Molecular cloning and characterization of a channel-like transporter mediating intestinal calcium absorption. J Biol Chem 274, 22739-22746.

50. Kim HJ, Lee GS, Ji YK, et al. (2006) Differential expression of uterine calcium transporter 1 and plasma membrane $\mathrm{Ca}^{2+}$ ATPase 1b during rat estrous cycle. Am J Physiol Endocrinol Metab 291, E234-E241.

51. Stauffer TP, Guerini D, Celio MR, et al. (1997) Immunolocalization of the plasma membrane $\mathrm{Ca}^{2+}$ pump isoforms in the rat brain. Brain Res $\mathbf{7 4 8}, 21-29$.

52. Tribe RM, Moriarty P \& Poston L (2000) Calcium homeostatic pathways change with gestation in human myometrium. Biol Reprod 63, 748-755.

53. Ghijsen WE, De Jong MD \& Van Os CH (1982) ATP-dependent calcium transport and its correlation with $\mathrm{Ca}^{2+}$-ATPase activity in basolateral plasma membranes of rat duodenum. Biochim Biophys Acta 28, 327-336.

54. Anderson RG (1993) Caveolae: where incoming and outgoing messengers meet. Proc Natl Acad Sci U S A 90, 10909-10913.

55. Centeno VA, Díaz de Barboza GE, Marchionatti AM, et al. (2004) Dietary calcium deficiency increases $\mathrm{Ca}^{2+}$ uptake and $\mathrm{Ca}^{2+}$ extrusion mechanisms in chick enterocytes. Comp Biochem Physiol A Mol Integr Physiol 139, 133-141.

56. Liu C, Weng H, Chen L, et al. (2013) Impaired intestinal calcium absorption in protein $4.1 \mathrm{R}$-deficient mice due to altered expression of plasma membrane calcium ATPase ${ }_{1 \mathrm{~b}}$ $\left(\mathrm{PMCA}_{1 \mathrm{~b}}\right)$. J Biol Chem 19, 11407-11415.

57. Ghijsen WE, De Jong MD \& Van Os CH (1983) Kinetic properties of $\mathrm{Na}^{+} / \mathrm{Ca}^{2+}$ exchange in basolateral plasma membranes of rat small intestine. Biochim Biophys Acta 730, 85-94.

58. Philipson KD, Nicoll DA, Matsuoka S, et al. (1996) Molecular regulation of the $\mathrm{Na}^{+}-\mathrm{Ca}^{2+}$ exchanger. Ann $N$ Y Acad Sci 779, 20-28.

59. Dong H, Sellers ZM, Smith A, et al. (2005) $\mathrm{Na}^{+} / \mathrm{Ca}^{2+}$ exchange regulates $\mathrm{Ca}^{2+}$-dependent duodenal mucosal ion transport and $\mathrm{HCO}_{3-}$ secretion in mice. Am J Physiol Gastrointest Liver Physiol 288, G457-G465.

60. Hwang I, Jung EM, Yang H, et al. (2011) Tissue-specific expression of the calcium transporter genes TRPV5, TRPV6, NCX1, and PMCA1b in the duodenum, kidney and heart of Equus caballus. J Vet Med Sci 73, 1437-1444.

61. Kim JA, Yang H, Hwang I, et al. (2011) Expression patterns and potential action of the calcium transport genes Trpv5, Trpv6, Ncx 1 and $P_{m c a_{1 b}}$ in the canine duodenum, kidney and uterus. In Vivo 25, 773-780.

62. Hoenderop JG, Hartog A, Stuiver M, et al. (2000) Localization of the epithelial $\mathrm{Ca}^{2+}$ channel in rabbit kidney and intestine. J Am Soc Nephrol 11, 1171-1178.

63. Blaustein MP \& Lederer WJ (1999) Sodium/calcium exchange: its physiological implications. Physiol Rev 79, 763-854.

64. Yang H, Lei C, Cheng C, et al. (2012) The antiapoptotic effect of galectin-3 in human endometrial cells under the regulation of estrogen and progesterone. Biol Reprod 87, 39.

65. Hoenderop JG, Nilius B \& Bindels RJ (2005) Calcium absorption across epithelia. Physiol Rev 85, 373-422.

66. González-Mariscal L, Betanzos A, Nava P, et al. (2003) Tight junction proteins. Prog Biophys Mol Biol 81, 1-44.

67. Bronner F \& Pansu D (1999) Nutritional aspects of calcium absorption. J Nutr 129, 9-12.
68. Bronner F (2003) Mechanisms of intestinal calcium absorption. J Cell Biochem 88, 387-393.

69. Bouillon R, Lieben L, Mathieu C, et al. (2013) Vitamin D action: lessons from VDR and Cyp27b1 null mice. Pediatr Endocrinol Rev 10, 354-366.

70. Wasserman RH, Smith CA, Brindak ME, et al. (1992) Vitamin D and mineral deficiencies increase the plasma membrane calcium pump of chicken intestine. Gastroenterology 102, 886-894.

71. Centeno V, Picotto G \& Pérez A (2011) Intestinal $\mathrm{Na}^{+} / \mathrm{Ca}^{2+}$ exchanger protein and gene expression are regulated by $1,25(\mathrm{OH})_{2} \mathrm{D}_{3}$ in vitamin D-deficient chicks. Arch Biochem Biophys 15, 191-196.

72. Balesaria S, Sangha S \& Walters JR (2009) Human duodenum responses to vitamin D metabolites of TRPV6 and other genes involved in calcium absorption. Am J Physiol Gastrointest Liver Physiol 297, G1193-G1197.

73. Khuituan P, Wongdee K, Jantarajit W, et al. (2013) Fibroblast growth factor-23 negates $1,25(\mathrm{OH})_{2} \mathrm{D}_{3}$-induced intestinal calcium transport by reducing the transcellular and paracellular calcium fluxes. Arch Biochem Biophys 536, 46-52.

74. Fudge NJ \& Kovacs CS (2010) Pregnancy up-regulates intestinal calcium absorption and skeletal mineralization independently of the vitamin D receptor. Endocrinology 151, 886-895.

75. Gallagher JC (2013) Vitamin D and aging. Endocrinol Metab Clin North Am 42, 319-332.

76. Sheikh MS, Schiller LR, Fordtran JS, et al. (1990) In vivo intestinal absorption of calcium in humans. Miner Electrolyte Metab 16, 130-146.

77. Karbach U (1992) Paracellular calcium transport across the small intestine. J Nutr 122, 672-677.

78. Fujita H, Sugimoto K, Inatomi S, et al. (2008) Tight junction proteins claudin-2 and -12 are critical for vitamin D-dependent $\mathrm{Ca}^{2+}$ absorption between enterocytes. Mol Biol Cell 19, 1912-1921.

79. Garg MK, Kalra S \& Mahalle N (2013) Defining vitamin D deficiency using surrogate markers. Indian J Endocrinol Metab 17, 784-786.

80. Picotto G, Massheimer V \& Boland R (1997) Parathyroid hormone stimulates calcium influx and the cAMP messenger system in rat enterocytes. Am J Physiol 273, C1349-C1353.

81. Gentili C, Morelli S \& de Boland AR (2003) Characterization of PTH/PTHrP receptor in rat duodenum: effects of ageing. $J$ Cell Biochem 88, 1157-1167.

82. Nemere I \& Larsson D (2002) Does PTH have a direct effect on intestine? J Cell Biochem 86, 29-34.

83. Cross HS, Debiec H \& Peterlik M (1990) Thyroid hormone enhances the genomic action of calcitriol in the small intestine. Prog Clin Biol Res 332, 163-180.

84. Kumar V \& Prasad R (2003) Thyroid hormones stimulate calcium transport systems in rat intestine. Biochim Biophys Acta 1639, 185-194.

85. Zoidis E, Gosteli-Peter M, Ghirlanda-Keller C, et al. (2002) IGF-I and GH stimulate Phex mRNA expression in lungs and bones and 1,25-dihydroxyvitamin $\mathrm{D}_{3}$ production in hypophysectomized rats. Eur J Endocrinol 146, 97-105.

86. Fleet JC, Bruns ME, Hock JM, et al. (1994) Growth hormone and parathyroid hormone stimulate intestinal calcium absorption in aged female rats. Endocrinology 134, 1755-1760.

87. Fatayerji D, Mawer EB \& Eastell R (2000) The role of insulinlike growth factor I in age-related changes in calcium homeostasis in men. J Clin Endocrinol Metab 85, 4657-4662.

88. Cotter AA \& Cashman KD (2006) Effect of $17 \beta$-oestradiol on transepithelial calcium transport in human intestinal-like Caco-2 cells and its interactions with 1,25-dihydroxycholecalciferol and 9-cis retinoic acid. Eur J Nutr 45, 234-241. 
89. Colin EM, Van Den Bemd GJ, Van Aken M, et al. (1999) Evidence for involvement of $17 \beta$-estradiol in intestinal calcium absorption independent of 1,25-dihydroxyvitamin $\mathrm{D}_{3}$ level in the rat. J Bone Miner Res 14, 57-64.

90. Bouillon R, Carmeliet G \& Van Cromphaut S (2005) Intestinal calcium absorption: lessons from knockout mice and men. In Vitamin D, 2nd ed., pp. 429-452 [D Feldman, FH Glorieux and JW Pike, editors]. San Diego, CA: Academic Press

91. Campbell-Thompson M, Lynch IJ, Bhardwaj B, et al. (2001) Expression of estrogen receptor (ER) subtypes and ER $\beta$ isoforms in colon cancer. Cancer Res 61, 632-640.

92. van Abel M, Hoenderop JG, van der Kemp AW, et al. (2003) Regulation of the epithelial $\mathrm{Ca}^{2+}$ channels in small intestine as studied by quantitative mRNA detection. Am J Physiol Gastrointest Liver Physiol 285, G78-G85.

93. Cotter AA \& Cashman KD (2005) The effect of two dietary and a synthetic phytoestrogen on transepithelial calcium transport in human intestinal-like Caco-2 cells. Eur J Nutr $\mathbf{4 4}$, 72-78.

94. Park CY \& Weaver CM (2012) Vitamin D interactions with soy isoflavones on bone after menopause: a review. Nutrients 4, 1610-1621.

95. Reid IR (1997) Glucocorticoid osteoporosis - mechanisms and management. Eur J Endocrinol 137, 209-217.

96. Van Cromphaut SJ, Stockmans I, Torrekens S, et al. (2007) Duodenal calcium absorption in dexamethasone-treated mice: functional and molecular aspects. Arch Biochem Biophys 460, 300-305.

97. Lee GS, Choi KC, Jeung EB, et al. (2006) Glucocorticoids differentially regulate expression of duodenal and renal calbindin- $\mathrm{D}_{9 \mathrm{k}}$ through glucocorticoid receptor-mediated pathway in mouse model. Am J Physiol Endocrinol Metab 290, E299-E307.

98. Huybers S, Naber TH, Bindels RJ, et al. (2007) Prednisoloneinduced $\mathrm{Ca}^{2+}$ malabsorption is caused by diminished expression of the epithelial $\mathrm{Ca}^{2+}$ channel TRPV6. $\mathrm{Am}$ Physiol Gastrointest Liver Physiol 292, G92-G97.

99. Christakos S, Dhawan P \& Liu Y (2003) New insights into the mechanisms of vitamin D action. $J$ Cell Biochem $\mathbf{8 8}$, 695-705.

100. Brown AJ, Krits I \& Armbrecht HJ (2005) Effect of age, vitamin $\mathrm{D}$, and calcium on the regulation of rat intestinal epithelial calcium channels. Arch Biochem Biophys 437, $51-58$.

101. Benn BS, Ajibade D \& Porta A (2008) Active intestinal calcium transport in the absence of transient receptor potential vanilloid type 6 and calbindin- $\mathrm{D}_{9 \mathrm{k}}$. Endocrinology 149, 3196-3205.

102. Tolosa de Talamoni N, Mykkanen H \& Wasserman RH (1990) Enhancement of sulfhydryl group availability in the intestinal brush border membrane by deficiencies of dietary calcium and phosphorus in chicks. J Nutr 120, 1198-1204.

103. Brun LR, Brance ML \& Rigalli A (2012) Luminal calcium concentration controls intestinal calcium absorption by modification of intestinal alkaline phosphatase activity. $\mathrm{Br} \mathrm{J}$ Nutr 108, 229-233.

104. Zemel MB, Shi H, Greer B, et al. (2000) Regulation of adiposity by dietary calcium. FASEB J 14, 1132-1138.

105. Zemel MB (2005) The role of dairy foods in weight management. J Am Coll Nutr 24, 537S-546S.

106. Huang JY \& Qi SJ (2015) Childhood obesity and food intake. World J Pediatr 11, 101-107.

107. Barr S (2003) Increased dairy product or calcium intake: is body weight or composition affected in humans? J Nutr $\mathbf{1 3 3}$ 245S-248S
108. Coe FL, Favus MJ \& Asplin JR (2004) Nephrolithiasis. In The Kidney, 7th ed., pp. 1819-1866 [BM Brenner and FC Rector, editors]. Philadelphia, PA: Elsevier.

109. Lemann J (2002) Idiopathic hypercalciuria. In Disorders of Bone and Mineral Metabolism, pp. 673-697 [FL Coe and M Favus, editors]. Philadelphia, PA: Lippincott.

110. Haghighi A, Samimagham H \& Gohardehi G (2013) Calcium and vitamin D supplementation and risk of kidney stone formation in postmenopausal women. Iran J Kidney Dis 7, 210-213.

111. Jackson RD, LaCroix AZ, Gass M, et al. (2006) Calcium plus vitamin D supplementation and the risk of fractures. $N$ Engl J Med 354, 669-683.

112. Diaz-Lopez B \& Cannata-Andia JB (2006) Supplementation of vitamin D and calcium: advantages and risks. Nephrol Dial Transplant 21, 2375-2377.

113. Curhan GC, Willett WC, Rimm EB, et al. (1993) A prospective study of dietary calcium and other nutrients and the risk of symptomatic kidney stones. N Engl J Med 328, 833-838.

114. Borghi L, Schianchi T, Meschi T, et al. (2002) Comparison of two diets for the prevention of recurrent stones in idiopathic hypercalciuria. $N$ Engl J Med 346, 77-84.

115. Park Y, Leitzmann MF, Subar A, et al. (2009) Dairy food, calcium, and risk of cancer in the NIH-AARP diet and health study. Arch Intern Med 169, 391-401.

116. Tárraga López PJ, Albero JS \& Rodríguez-Montes JA (2014) Primary and secondary prevention of colorectal cancer. Clin Med Insights Gastroenterol 7, 33-46.

117. Peterlik M, Grant WB \& Cross HS (2009) Calcium, vitamin D and cancer. Anticancer Res 29, 3687-3698.

118. McCullough ML, Rodriguez C, Diver WR, et al. (2005) Dairy, calcium, and vitamin D intake and postmenopausal breast cancer risk in the Cancer Prevention Study II Nutrition Cohort. Cancer Epidemiol Biomarkers Prev 14, 2898-2904.

119. Hong Z, Tian C \& Zhang X (2012) Dietary calcium intake, vitamin $\mathrm{D}$ levels, and breast cancer risk: a dose-response analysis of observational studies. Breast Cancer Res Treat 136, 309-312.

120. Chen P, Hu P, Xie D, et al. (2010) Meta-analysis of vitamin D, calcium and the prevention of breast cancer. Breast Cancer Res Treat 121, 469-477.

121. Vergne Y, Matta J, Morales L, et al. (2007) Intakes of calcium and vitamin D and breast cancer risk in women. Arch Intern Med 167, 1050-1059.

122. Belizan JM \& Villar J (1980) The relationship between calcium intake and edema-, proteinuria-, and hypertensiongetosis: an hypothesis. Am J Clin Nutr 33, 2202-2210.

123. Belizan JM, Villar J \& Repke J (1988) The relationship between calcium intake and pregnancy-induced hypertension: up-to-date evidence. Am J Obstet Gynecol 158, 898-902.

124. Camargo EB, Moraes LF, Souza CM, et al. (2013) Survey of calcium supplementation to prevent preeclampsia: the gap between evidence and practice in Brazil. BMC Pregnancy Childbirth 13, 206

125. Griffith LE, Guyatt GH \& Cook RJ (1999) The influence of dietary and nondietary calcium supplementation on blood pressure: an updated metaanalysis of randomized controlled trials. Am J Hypertens 12, 84-92.

126. van Mierlo LA, Arends LR, Streppel MT, et al. (2006) Blood pressure response to calcium supplementation: a metaanalysis of randomized controlled trials. J Hum Hypertens 20, 571-580.

127. Varenna M, Manara M, Galli L, et al. (2013) The association between osteoporosis and hypertension: the role of a low dairy intake. Calcif Tissue Int 93, 86-92. 
128. Reid IR, Mason B, Horne A, et al. (2006) Randomized controlled trial of calcium in healthy older women. Am J Med 119, 777-785.

129. Kim KM, Choi SH, Lim S, et al. (2014) Interactions between dietary calcium intake and bone mineral density or bone geometry in a low calcium intake population. J Clin Endocrinol Metab 99, 2409-2417.

130. Zhou W, Langsetmo L, Berger C, et al. (2013) Longitudinal changes in calcium and vitamin $\mathrm{D}$ intakes and relationship to bone mineral density in a prospective population-based study: the Canadian Multicentre Osteoporosis Study (CaMos). J Musculoskelet Neuronal Interact 13, 470-479.

131. Adler AJ \& Berlyne GM (1985) Duodenal aluminum absorption in the rat: effect of vitamin D. Am J Physiol 249, G209-G213.

132. Dunn MA, Johnson NE, Liew MY, et al. (1993) Dietary aluminum chloride reduces the amount of intestinal calbindin D-28K in chicks fed low calcium or low phosphorus diets. J Nutr 123, 1786-1793.

133. Cox KA \& Dunn MA (2001) Aluminum toxicity alters the regulation of calbindin-D28k protein and mRNA expression in chick intestine. J Nutr 131, 2007-2013.

134. Orihuela D, Meichtry V, Pregi N, et al. (2005) Short-term oral exposure to aluminium decreases glutathione intestinal levels and changes enzyme activities involved in its metabolism. J Inorg Biochem 99, 1871-1878.

135. Orihuela D, Meichtry V \& Pizarro M (2005) Aluminiuminduced impairment of transcellular calcium absorption in the small intestine: calcium uptake and glutathione influence. J Inorg Biochem 99, 1879-1886.

136. Orihuela D (2009) Inhibitory effect of aluminium on calcium absorption in small intestine of rats with different thyroid hormone status. J Inorg Biochem 103, 1542-1547.

137. Orihuela D (2007) Effect of aluminium on duodenal calcium transport in pregnant and lactating rats treated with bromocriptine. J Inorg Biochem 101, 1270-1274.

138. Heaney RP \& Nordin BE (2002) Calcium effects on phosphorus absorption: implications for the prevention and co-therapy of osteoporosis. J Am Coll Nutr 21, 239-244.

139. Ribovich ML \& DeLuca HF (1978) Effect of dietary calcium and phosphorus on intestinal calcium absorption and vitamin D metabolism. Arch Biochem Biophys 188, 145-156.

140. Gray RW \& Napoli JL (1983) Dietary phosphate deprivation increases 1,25-dihyroxyvitamin $\mathrm{D}_{3}$ synthesis in rat kidney in vitro. J Biol Chem 258, 1152-1155.

141. Meyer RA Jr, Tenenhouse HS, Meyer MH, et al. (1989) The renal phosphate transport defect in normal mice parabiosed to $\mathrm{X}$-linked hypophosphatemic mice persists after parathyroidectomy. J Bone Miner Res 4, 523-532.

142. Bar A \& Wasserman RH (1973) Control of calcium absorption and intestinal calcium-binding protein synthesis. Biochem Biophys Res Commun 54, 191-196.

143. Meyer J, Fullmer CS, Wasserman RH, et al. (1992) Dietary restriction of calcium, phosphorus, and vitamin D elicits differential regulation of the mRNAs for avian intestinal calbindin-D28k and the 1,25-dihydroxyvitamin $\mathrm{D}_{3}$ receptor. J Bone Miner Res 7, 441-448.

144. Hendrix ZJ, Alcock NW \& Archibald RM (1963) competition between calcium, strontium, and magnesium for absorption in the isolated rat intestine. Clin Chem 12, 734-744.

145. O'Donnell JM \& Smith MW (1973) Uptake of calcium and magnesium by rat duodenal mucosa analysed by means of competing metals. J Physiol 229, 733-749.

146. Hardwick LL, Jones MR, Brautbar N, et al. (1991) Magnesium absorption: mechanisms and the influence of vitamin D, calcium and phosphate. J Nutr 121, 13-23.
147. de Swart PM, Sokole EB \& Wilmink JM (1998) The interrelationship of calcium and magnesium absorption in idiopathic hypercalciuria and renal calcium stone disease. J Urol 159, 669-672.

148. Planells E, Sánchez-Morito N, Montellano MA, et al. (2000) Effect of magnesium deficiency on enterocyte $\mathrm{Ca}, \mathrm{Fe}, \mathrm{Cu}, \mathrm{Zn}$, Mn and Se content. J Physiol Biochem 56, 217-222.

149. Dimai H-P, Porta S, Wirnsberger G, et al. (1998) Daily oral magnesium supplementation suppresses bone turnover in young adult males. J Clin Endocrinol Metab 83, 2742-2748.

150. Fine KD, Santa Ana CA, Porter JL, et al. (1991) Intestinal absorption of magnesium from food and supplements. J Clin Invest 88, 396-402.

151. Kozakai T, Uozumi N, Katoh K, et al. (2002) Dietary magnesium increases calcium absorption of ovine small intestine in vivo and in vitro. Reprod Nutr Dev 42, 25-33.

152. Bae YJ, Bu SY, Kim JY, et al. (2011) Magnesium supplementation through seaweed calcium extract rather than synthetic magnesium oxide improves femur bone mineral density and strength in ovariectomized rats. Biol Trace Elem Res 144, 992-1002.

153. Hessov I, Andersson H \& Isaksson B (1983) Effects of a lowfat diet on mineral absorption in small-bowel disease. Scand $J$ Gastroenterol 18, 551-554.

154. Haderslev KV, Jeppesen PB, Mortensen PB, et al. (2000) Absorption of calcium and magnesium in patients with intestinal resections treated with medium chain fatty acids. Gut 46, 819-823.

155. Jewell C, Cusack S \& Cashman KD (2005) The effect of conjugated linoleic acid on transepithelial calcium transport and mediators of paracellular permeability in human intestinal-like Caco-2 cells. Prostaglandins Leukot Essent Fatty Acids 72, 163-171.

156. Murphy EF, Jewell C, Hooiveld GJ, et al. (2006) Conjugated linoleic acid enhances transepithelial calcium transport in human intestinal-like Caco-2 cells: an insight into molecular changes. Prostaglandins Leukot Essent Fatty Acids 74, 295-301.

157. Coxam V (2007) Current data with inulin-type fructans and calcium, targeting bone health in adults. J Nutr 137, 2527S-2533S

158. Raschka L \& Daniel H (2005) Diet composition and age determine the effects of inulin-type fructans on intestinal calcium absorption in rat. Eur J Nutr 44, 360-364.

159. Lobo AR, Cocato ML \& Jorgetti V (2009) Changes in bone mass, biomechanical properties, and microarchitecture of calcium- and iron-deficient rats fed diets supplemented with inulin-type fructans. Nutr Res 29, 873-881.

160. Xiao Y, Cui J, Shi YH, et al. (2010) Effects of duodenal redox status on calcium absorption and related genes expression in high-fat diet-fed mice. Nutrition 26, 1188-1194.

161. Buchowski MS \& Miller DD (1991) Lactose, calcium source and age affect calcium bioavailability in rats. $J$ Nutr $\mathbf{1 2 1}$, 1746-1754.

162. Dupuis Y, Tardivel S, Porembska Z, et al. (1991) Effect of some alkaline phosphatase inhibitors on intestinal calcium transfer. Int J Biochem 23, 175-180.

163. Sogabe N, Mizoi L, Asahi K, et al. (2004) Enhancement by lactose of intestinal alkaline phosphatase expression in rats. Bone 35, 249-255.

164. Nishimukai M, Watanabe J, Taguchi H, et al. (2008) Effects of epilactose on calcium absorption and serum lipid metabolism in rats. J Agric Food Chem 56, 10340-10345.

165. Suzuki T, Nishimukai M, Shinoki A, et al. (2010) Ingestion of epilactose, a non-digestible disaccharide, improves postgastrectomy osteopenia and anemia in rats through the 
promotion of intestinal calcium and iron absorption. J Agric Food Chem 58, 10787-10792.

166. Suzuki T, Nishimukai M, Takechi M, et al. (2010) The nondigestible disaccharide epilactose increases paracellular $\mathrm{Ca}$ absorption via rho-associated kinase- and myosin light chain kinase-dependent mechanisms in rat small intestines. I Agric Food Chem 58, 1927-1932.

167. Mineo H, Hara H \& Tomita F (2002) Sugar alcohols enhance calcium transport from rat small and large intestine epithelium in vitro. Dig Dis Sci 47, 1326-1333.

168. Xiao J, Li X, Min X, et al. (2013) Mannitol improves absorption and retention of calcium and magnesium in growing rats. Nutrition 29, 325-331.

169. López-Huertas E, Teucher B, Boza JJ, et al. (2006) Absorption of calcium from milks enriched with fructo-oligosaccharides, caseinophosphopeptides, tricalcium phosphate, and milk solids. Am J Clin Nutr 83, 310-316.

170. Scholz-Ahrens KE, Schaafsma G, van den Heuvel EG, et al. (2001) Effects of prebiotics on mineral metabolism. Am J Clin Nutr 73, 459S-464S

171. Suzuki T \& Hara H (2004) Various non-digestible saccharides increase intracellular calcium ion concentration in rat smallintestinal enterocytes. Br J Nutr 92, 751-755.

172. Takasaki M, Inaba H, Ohta A, et al. (2000) Dietary shortchain fructooligosaccharides increase calbindin-D9k levels only in the large intestine in rats independent of dietary calcium deficiency or serum 1,25 dihydroxy vitamin D levels. Int J Vitam Nutr Res 70, 206-213.

173. Fukushima A, Aizaki Y \& Sakuma K (2009) Short-chain fatty acids induce intestinal transient receptor potential vanilloid type 6 expression in rats and Caco-2 cells. J Nutr 139, 20-25.

174. Legette LL, Lee W, Martin BR, et al. (2012) Prebiotics enhance magnesium absorption and inulin-based fibers exert chronic effects on calcium utilization in a postmenopausal rodent model. I Food Sci 77, H88-H94.

175. Weaver CM, Martin BR, Nakatsu CH, et al. (2011) Galactooligosaccharides improve mineral absorption and bone properties in growing rats through gut fermentation. J Agric Food Chem 59, 6501-6510.

176. Tsuchita H, Suzuki T \& Kuwata T (2001) The effect of casein phosphopeptides on calcium absorption from calciumfortified milk in growing rats. Br J Nutr 85, 5-10.

177. Erba D, Ciappellano S \& Testolin G (2002) Effect of the ratio of casein phosphopeptides to calcium $(\mathrm{w} / \mathrm{w})$ on passive calcium transport in the distal small intestine of rats. Nutrition 18, 743-746.

178. Teucher B, Majsak-Newman G, Dainty JR, et al. (2006) Calcium absorption is not increased by caseinophosphopeptides. Am J Clin Nutr 84, 162-166.

179. Cosentino S, Gravaghi C, Donetti E, et al. (2010) Caseinphosphopeptide-induced calcium uptake in human intestinal cell lines HT-29 and $\mathrm{CacO} 2$ is correlated to cellular differentiation. J Nutr Biochem 21, 247-254.

180. Colombini A, Perego S, Ardoino I, et al. (2013) Evaluation of a possible direct effect by casein phosphopeptides on paracellular and vitamin D controlled transcellular calcium transport mechanisms in intestinal human HT-29 and Caco2 cell lines. Food Funct 4, 1195-1203.

181. Whisner CM, Martin BR \& Nakatsu CH (2014) Soluble maize fibre affects short-term calcium absorption in adolescent boys and girls: a randomised controlled trial using dual stable isotopic tracers. Br J Nutr 112, 446-456.

182. Schrezenmeir J \& de Vrese M (2001) Probiotics, prebiotics, and synbiotics - approaching a definition. Am J Clin Nutr $\mathbf{7 3}$, 361S-364S
183. Ghanem KZ, Badawy IH \& Abdel-Samam AM (2004) Influence of yogourt and probiotic yogourt on the absorption of calcium, magnesium, iron and bone mineralization in rats. Milchwissenschaft 59, 472-475.

184. Gilman J \& Cashman KD (2006) The effect of probiotic bacteria on transepithelial calcium transport and calcium uptake in human intestinal-like Caco-2 cells. Curr Issues Intest Microbiol 7, 1-5.

185. Scholz-Ahrens K, Ade P, Marten B, et al. (2007) Prebiotics, probiotics, and synbiotics affect mineral absorption, bone mineral content, and bone structure. J Nutr 137, 838S-846S.

186. Kerstetter JE, O’Brien KO \& Insogna KL (2003) Low protein intake: the impact on calcium and bone homeostasis in humans. J Nutr 133, 855S-861S.

187. Johnson NE, Alcantara EN \& Linkswiler H (1970) Effect of level of protein intake on urinary and fecal calcium and calcium retention of young adult males. $J$ Nutr $\mathbf{1 0 0}$, $1425-1430$

188. Darling AL, Millward DJ, Torgerson DJ, et al. (2009) Dietary protein and bone health: a systematic review and metaanalysis. Am J Clin Nutr 90, 1674-1692.

189. Kerstetter JE, O'Brien KO, Caseria DM, et al. (2005) The impact of dietary protein on calcium absorption and kinetic measures of bone turnover in women. J Clin Endocrinol Metab 90, 26-31.

190. Gaffney-Stomberg E, Sun BH, Cucchi CE, et al. (2010) The effect of dietary protein on intestinal calcium absorption in rats. Endocrinology 151, 1071-1078.

191. Skipper A (2010) Nutrition Care Manual. Chicago, IL. American Dietetic Association, American Dietetic Association Nutrition Care Manual. http://www.nutritioncaremanual.org (accessed September 2015).

192. Marcason W (2010) What is the effect of a high-protein diet on bone health? J Am Diet Assoc 110, 812.

193. Das AS, Das D, Mukherjee M, et al. (2005) Phytoestrogenic effects of black tea extract (Camellia sinensis) in an oophorectomized rat (Rattus norvegicus) model of osteoporosis. Life Sci 77, 3049-3057.

194. Sharma V \& Rao LJ (2009) A thought on the biological activities of black tea. Crit Rev Food Sci Nutr 49, 379-404.

195. Das AS, Banerjee M, Das D, et al. (2013) Black tea may be a prospective adjunct for calcium supplementation to prevent early menopausal bone loss in a rat model of osteoporosis. J Osteoporos 2013, 760586.

196. Hernandez-Avila M, Colditz GA, Stampfer MJ, et al. (1991) Caffeine, moderate alcohol intake, and risk of fractures of the hip and forearm in middle-aged women. Am J Clin Nutr $\mathbf{5 4}$, 157-163.

197. Welch AA, Bingham SA, Reeve J, et al. (2007) More acidic dietary acid-base load is associated with reduced calcaneal broadband ultrasound attenuation in women but not in men: results from the EPIC-Norfolk cohort study. Am J Clin Nutr 85, 1134-1141.

198. Cooper C, Atkinson EJ, Wahner HW, et al. (1992) Is caffeine consumption a risk factor for osteoporosis? J Bone Miner Res 7, 465-471

199. Huopio J, Kröger H, Honkanen R, et al. (2000) Risk factors for perimenopausal fractures: a prospective study. Osteoporos Int 11, 219-227.

200. Hallström H, Byberg L, Glynn A, et al. (2013) Long-term coffee consumption in relation to fracture risk and bone mineral density in women. Am J Epidemiol 178, 898-909.

201. Yeh JK \& Aloia JF (1986) Differential effect of caffeine administration on calcium and vitamin D metabolism in young and adult rats. J Bone Miner Res 1, 251-258. 
202. Hasling C, Søndergaard K, Charles P, et al. (1992) Calcium metabolism in postmenopausal osteoporotic women is determined by dietary calcium and coffee intake. J Nutr $\mathbf{1 2 2}$, 1119-1126.

203. Folwarczna J, Pytlik M, Zych M, et al. (2013) Favorable effect of moderate dose caffeine on the skeletal system in ovariectomized rats. Mol Nutr Food Res 57, 1772-1784.

204. Cano-Marquina A, Tarín JJ \& Cano A (2013) The impact of coffee on health. Maturitas 75, 7-21.

205. Folwarczna J, Zych M, Nowińska B, et al. (2014) Unfavorable effect of trigonelline, an alkaloid present in coffee and fenugreek, on bone mechanical properties in estrogendeficient rats. Mol Nutr Food Res 58, 1457-1464.

206. Lowe M, Strauss AW, Alpers R, et al. (1990) Molecular cloning and expression of a cDNA encoding the membrane-associated rat intestinal alkaline phosphatase. Biochim Biophys Acta 1037, 170-177.

207. Marchionatti A, Alisio A, Díaz de Barboza G, et al. (2001) DL-Buthionine-S,R-sulfoximine affects intestinal alkaline phosphatase activity. Comp Biochem Physiol C Toxicol Pharmacol 129, 85-91.

208. Chiou TJ \& Tzeng WF (2000) The roles of glutathione and antioxidant enzymes in menadione-induced oxidative stress. Toxicology 154, 75-84.

209. Shiraki M, Shiraki Y, Aoki C, et al. (2000) Vitamin $\mathrm{K}_{2}$ (menatetrenone) effectively prevents fractures and sustains lumbar bone mineral density in osteoporosis. J Bone Miner Res 15, 515-521.

210. Sata N, Klonowski-Stumpe H, Han B, et al. (1997) Menadione induces both necrosis and apoptosis in rat pancreatic acinar AR4-2J cells. Free Radic Biol Med 23, 844-850.

211. Marchionatti AM, Díaz de Barboza GE, Centeno VA, et al. (2003) Effects of a single dose of menadione on the intestinal calcium absorption and associated variables. J Nutr Biochem 14, 466-472.

212. Higuchi Y (2004) Glutathione depletion-induced chromosomal DNA fragmentation associated with apoptosis and necrosis. $J$ Cell Mol Med 8, 455-464.

213. Marchionatti AM, Perez AV, Diaz de Barboza GE, et al. (2008) Mitochondrial dysfunction is responsible for the intestinal calcium absorption inhibition induced by menadione. Biochim Biophys Acta 1780, 101-107.

214. Suzuki T \& Hara H (2009) Quercetin enhances intestinal barrier function through the assembly of zonula [corrected] occludens-2, occludin, and claudin- 1 and the expression of claudin-4 in Caco-2 cells. J Nutr 139, 965-974.

215. Marchionatti AM, Pacciaroni A \& Tolosa de Talamoni NG (2013) Effects of quercetin and menadione on intestinal calcium absorption and the underlying mechanisms. Comp Biochem Physiol A Mol Integr Physiol 164, 215-220.

216. Carpentieri A, Marchionatti A, Areco V, et al. (2014) Antioxidant and antiapoptotic properties of melatonin restore intestinal calcium absorption altered by menadione. Mol Cell Biochem 387, 197-205.

217. Rivoira MA, Marchionatti AM, Centeno VA, et al. (2012) Sodium deoxycholate inhibits chick duodenal calcium absorption through oxidative stress and apoptosis. Comp Biochem Physiol A Mol Integr Physiol 162, 397-405.

218. Lamireau T, Zoltowska M, Levy E, et al. (2003) Effects of bile acids on biliary epithelial cells: proliferation, cytotoxicity, and cytokine secretion. Life Sci 72, 1401-1411.

219. Kawano A, Ishikawa H, Kamano T, et al. (2010) Significance of fecal deoxycholic acid concentration for colorectal tumor enlargement. Asian Pac J Cancer Prev 11, 1541-1546.
220. Jean-Louis S, Akare S, Ali MA, et al. (2006) Deoxycholic acid induces intracellular signaling through membrane perturbations. J Biol Chem 281, 14948-14960.

221. Araki Y, Katoh T, Ogawa A, et al. (2005) Bile acid modulates transepithelial permeability via the generation of reactive oxygen species in the Caco-2 cell line. Free Radic Biol Med 39, 769-780.

222. Rodríguez V, Rivoira M, Marchionatti A, et al. (2013) Ursodeoxycholic and deoxycholic acids: a good and a bad bile acid for intestinal calcium absorption. Arch Biochem Biophys 540, 19-25.

223. Makishima M, Lu TT, Xie W, et al. (2002) Vitamin D receptor as an intestinal bile acid sensor. Science 296, $1313-1316$

224. Krasowski MD, Ni A, Hagey LR, et al. (2011) Evolution of promiscuous nuclear hormone receptors: LXR, FXR, VDR, PXR, and CAR. Mol Cell Endocrinol 334, 39-48.

225. D'Aldebert E, Biyeyeme Bi Mve MJ, Mergey M, et al. (2009) Bile salts control the antimicrobial peptide cathelicidin through nuclear receptors in the human biliary epithelium. Gastroenterology 136, 1435-1443.

226. Hansen KE, Jones AN, Lindstrom MJ, et al. (2010) Do proton pump inhibitors decrease calcium absorption? J Bone Miner Res 25, 2786-2789.

227. Wahl TO, Gobuty AH, Lukert BP, et al. (1981) Long-term anticonvulsant therapy and intestinal calcium absorption. Clin Pharmacol Ther 30, 506-512.

228. von Borstel Smith M, Crofoot K, Rodriguez-Proteau R, et al. (2007) Effects of phenytoin and carbamazepine on calcium transport in Caco-2 cells. Toxicol In Vitro $\mathbf{2 1}$, $855-862$.

229. Charoenphandhu N, Teerapornpuntakit J, Lapmanee S, et al. (2012) Duodenal calcium transporter mRNA expression in stressed male rats treated with diazepam, fluoxetine, reboxetine, or venlafaxine. $\mathrm{Mol}$ Cell Biochem 369, 87-94.

230. Kim S, An BS, Yang H, et al. (2013) Effects of octylphenol and bisphenol A on the expression of calcium transport genes in the mouse duodenum and kidney during pregnancy. Toxicology 303, 99-106.

231. Alevizaki CC, Ikkos DG \& Singhelakis P (1973) Progressive decrease of true intestinal calcium absorption with age in normal man. J Nucl Med 14, 760-762.

232. Chen C \& Kalu DN (1999) Strain differences in bone density and calcium metabolism between $\mathrm{C} 3 \mathrm{H} / \mathrm{HeJ}$ and $\mathrm{C} 57 \mathrm{BL} / 6 \mathrm{~J}$ mice. Bone 25, 413-420.

233. Wu L, Martin BR, Braun MM, et al. (2010) Calcium requirements and metabolism in Chinese-American boys and girls. $J$ Bone Miner Res 25, 1842-1849.

234. Weaver CM, McCabe LD, McCabe GP, et al. (2008) Vitamin D status and calcium metabolism in adolescent black and white girls on a range of controlled calcium intakes. J Clin Endocrinol Metab 93, 3907-3914.

235. Bryant RJ, Wastney ME, Martin BR, et al. (2003) Racial differences in bone turnover and calcium metabolism in adolescent females. J Clin Endocrinol Metab 88, 1043-1047.

236. Braun M, Palacios C, Wigertz K, et al. (2007) Racial differences in skeletal calcium retention in adolescent girls with varied controlled calcium intakes. Am J Clin Nutr 85, 1657-1663.

237. Replogle RA, Li Q, Wang L, et al. (2014) Gene-by-diet interactions influence calcium absorption and bone density in mice. J Bone Miner Res 29, 657-665.

238. Reid IR (2014) Should we prescribe calcium supplements for osteoporosis prevention? J Bone Metab 21, 21-28. 